\title{
The ballast effect of lithogenic matter and its influences on the carbon fluxes in the Indian Ocean
}

\author{
Tim Rixen ${ }^{1,2}$, Birgit Gaye ${ }^{2}$, Kay-Christian Emeis ${ }^{2,3}$, and Venkitasubramani Ramaswamy ${ }^{4}$ \\ ${ }^{1}$ Leibniz Center for Tropical Marine Research, 28359 Bremen, Germany \\ ${ }^{2}$ Institute for Geology, University of Hamburg, 20146 Hamburg, Germany \\ ${ }^{3}$ Helmholtz-Zentrum Geesthacht, Institute of Coastal Research, 21502 Geesthacht, Germany \\ ${ }^{4}$ National Institute of Oceanography, Dona Paula, Goa, 403004, India
}

Correspondence: Tim Rixen (tim.rixen@leibniz-zmt.de)

Received: 27 February 2018 - Discussion started: 29 March 2018

Revised: 27 November 2018 - Accepted: 4 December 2018 - Published: 29 January 2019

\begin{abstract}
Data obtained from long-term sediment trap experiments in the Indian Ocean in conjunction with satellite observations illustrate the influence of primary production and the ballast effect on organic carbon flux into the deep sea. They suggest that primary production is the main control on the spatial variability of organic carbon fluxes at most of our study sites in the Indian Ocean, except at sites influenced by river discharges. At these sites the spatial variability of organic carbon flux is influenced by lithogenic matter content. To quantify the impact of lithogenic matter on the organic carbon flux, the densities of the main ballast minerals, their flux rates and seawater properties were used to calculate sinking speeds of material intercepted by sediment traps. Sinking speeds in combination with satellite-derived export production rates allowed us to compute organic carbon fluxes. Flux calculations imply that lithogenic matter ballast increases organic carbon fluxes at all sampling sites in the Indian Ocean by enhancing sinking speeds and reducing the time of organic matter respiration in the water column. We calculated that lithogenic matter content in aggregates and pellets enhances organic carbon flux rates on average by $45 \%$ and by up to $62 \%$ at trap locations in the river-influenced regions of the Indian Ocean. Such a strong lithogenic matter ballast effect explains the fact that organic carbon fluxes are higher in the low-productive southern Java Sea compared to the high-productive western Arabian Sea. It also implies that land use changes and the associated enhanced transport of lithogenic matter from land into the ocean may significantly affect the $\mathrm{CO}_{2}$ uptake of the organic carbon pump in the receiving ocean areas.
\end{abstract}

\section{Introduction}

Photosynthesis and the export of organic matter from the euphotic zone into the deep sea drive the organic carbon pump and are integral parts of the global carbon cycle (Volk and Hoffert, 1985). The $\mathrm{CO}_{2}$ uptake in the ocean surface by phytoplankton and its transfer as sinking organic carbon through the thermocline and thus into the deep ocean is determined by available nutrients. The nutrients and $\mathrm{CO}_{2}$ associated with sinking organic matter are regenerated during passage through the water column and these "regenerated nutrients" comprise approximately $50 \%$ of the ocean's nutrient inventory. The other half, so-called "preformed nutrients" (Broecker et al., 1985), originate at high latitudes where light limits their complete utilisation in the biologically active zone before subduction (Duteil et al., 2012; Ito and Follows, 2005; Knox and McElroy, 1984; Sarmiento and Toggweiler, 1984; Siegenthaler and Wenk, 1984).

The ratio between total (regenerated and preformed) nutrient input into the ocean's surface mixed layer and their export as organic matter across the thermocline is a measure of the $\mathrm{CO}_{2}$ uptake efficiency by the organic carbon pump (DeVries et al., 2012). The efficiency is high in the subtropics and tropics where the ratio between preformed nutrient input and export as regenerated nutrients is close to one. The ballast effect modulates the efficiency of the organic carbon pump because the ballasting with lithogenic particles increases the sinking speeds of aggregates and thus the water depth at which sinking organic matter is respired (e.g. Haake and Ittekkot, 1990; Ittekkot, 1993; Kwon et al., 2009). If organic matter is respired within the euphotic zone, the released $\mathrm{CO}_{2}$ can 
immediately return into the atmosphere and nutrients are recycled. If it is respired in the deep sea, regenerated $\mathrm{CO}_{2}$ and nutrients are injected into the ocean's long-term overturning circulation, in which they can be stored for up to 1500 years (De La Rocha and Passow, 2014; Heinze et al., 1991). Accordingly, a significant ballast effect strengthens the organic carbon pump by extending the mean residence time of regenerated nutrients and $\mathrm{CO}_{2}\left(\mathrm{CO}_{2}\right.$ sequestration time) in the ocean (DeVries et al., 2012).

The ballast effect operates through two processes: minerals, which cause the ballast effect, can (i) adsorb and/or integrate organic molecules onto and into their structure (Armstrong et al., 2002) and (ii) increase the sinking speed of particles in which organic matter is exported from the euphotic zone (Haake and Ittekkot, 1990; Hamm, 2002; Ramaswamy et al., 1991). The former protects organic matter against remineralisation and the latter retards respiration in the water column.

Carbonate, biogenic opal and lithogenic matter are the main ballast minerals. Marine plankton produces carbonates and biogenic opal, whereas lithogenic matter is formed during weathering of rocks on land. Its input as dust and by rivers into the ocean is thus a steering mechanism linking the $\mathrm{CO}_{2}$ uptake of the organic carbon pump directly to processes on land (Ittekkot and Haake, 1990).

There is conflicting evidence for the roles of primary production and the ballast effect in organic matter export production in the literature. We adopt the term export production as corresponding to the organic carbon flux at a water depth of $100 \mathrm{~m}$ and use the term "organic carbon flux" for the organic carbon fluxes measured by sediment traps in the deep sea. Sediment trap experiments in the northern Indian Ocean have indicated that the Asian monsoon and its impacts on the nutrient supply into the euphotic zone (and thus primary production) primarily control organic carbon fluxes into the deep Arabian Sea and Bay of Bengal (Haake et al., 1993; Ittekkot et al., 1991; Nair et al., 1989; Rixen et al., 1996, 2009). But additionally, eolian dust inputs and discharges from rivers appeared to influence the ballast effect in these two basins (Ittekkot, 1993; Ittekkot and Haake, 1990). In the Bay of Bengal high detrital inputs may cause a stronger ballast effect, and a higher share of the organic matter exported from the euphotic zone reached the deep sea compared to the Arabian Sea (Rao et al., 1994).

A multiple linear regression (MLR) analysis of a global compilation of sediment trap data, including data from the Indian Ocean, surprisingly showed that primary production hardly affects organic carbon fluxes and that the ballast effect, dominated by carbonate minerals, controls the organic carbon export into the deep sea in the world's ocean (Klaas and Archer, 2002). This result was supported by Francois et al. (2002) who postulated that the contribution of lithogenic matter was too low to significantly contribute to the ballast effect, except in nearshore regions such as the Bay of Bengal. Based on an expanded global compilation of sediment trap data, a geographically weighted analysis identified both carbonate and lithogenic matter as the main ballast minerals in the Arabian Sea and the Bay of Bengal (Wilson et al., 2012), whereas another analysis of data from the Indian Ocean emphasised the role of biogenic opal as the main ballast mineral (Ragueneau et al., 2006). Thus, the role of primary production as the main driver of organic carbon fluxes is under scrutiny and all mineral components (lithogenic matter, carbonate and biogenic opal) have been identified as the "main ballast material" in the Indian Ocean. To re-evaluate evidence and in an attempt to quantify the influence of primary production and the impact of individual ballast minerals on organic carbon fluxes in the Indian Ocean, we compiled data sets of sediment trap results (Fig. 1, Table 1) and applied the MLR technique to segregate regional patterns of dominant controls on organic carbon fluxes. Furthermore, densities of ballast minerals were compiled from the literature and used jointly with measured fluxes, satellite-derived export production rate estimates and water column properties obtained from the World Ocean Atlas 2013 (Locarnini et al., 2013; Zweng et al., 2013) to calculate sinking speeds and organic carbon fluxes. This new mechanistic approach allows us to quantify the strength of the lithogenic matter ballast effect.

\section{Study area}

The Asian monsoon strongly influences the northern Indian Ocean with its two semi-enclosed basins: the Arabian Sea and the Bay of Bengal. Sea-level pressure differences between the Asian land mass and the Indian Ocean drive the monsoon (Ramage, 1987, 1971). Following the pressure gradient and deflected by the Coriolis force, wind blows from the NE over the Arabian Sea and the Bay of Bengal in winter between December and February (Currie et al., 1973). In summer (June-September), the situation reverses. The heating of the Asian land mass leads to the formation of a strong atmospheric low which attracts and enforces the SE trade winds to cross the Equator in the western Indian Ocean. They form a strong low-level jet (Findlater jet) blowing from the SW over the Arabian Sea (Fig. 2a, b; Findlater, 1969, 1977).

In the Arabian Sea, the positive wind stress curl west of the axis of the Findlater jet causes upwelling, which is strongest along the coast of the Arabian Peninsula (Bauer et al., 1991; Luther and O'Brien, 1990; Ryther and Menzel, 1965; Sastry and D'Souza, 1972). Weaker upwelling systems also occur NE of Sri Lanka and along the SW coast of India (Sharma, 1978; Shetye et al., 1990; Wiggert et al., 2006) and these signals are carried by the Southwest Monsoon Current into the southern Bay of Bengal (Unger et al., 2003). Due to the northward movements of the SE trade wind systems and the associated reversal of the South Java Current an upwelling system emerges off southern Java and Bali almost simultaneously with the development of the Findlater Jet in the Ara- 
Table 1. Number of station, trap ID, station name, position, water depth and trap depth.

\begin{tabular}{lllrrrr}
\hline No. & Trap ID & Name & $\begin{array}{r}\text { Lat. } \\
\left({ }^{\circ} \mathrm{N}\right)\end{array}$ & $\begin{array}{r}\text { Long. } \\
\left({ }^{\circ} \mathrm{N}\right)\end{array}$ & $\begin{array}{r}W \text { depth } \\
(\mathrm{m})\end{array}$ & $\begin{array}{r}T \text { depth } \\
(\mathrm{m})\end{array}$ \\
\hline 1 & WAST & Western Arabian Sea Trap Station & 16.26 & 60.58 & 4032 & 3017 \\
2 & CAST & Central Arabian Sea Trap Station & 14.51 & 64.72 & 3920 & 2944 \\
3 & EAST & Eastern Arabian Sea Trap Station & 15.57 & 68.73 & 3791 & 2870 \\
4 & NEAST & Northeastern Arabian Sea Trap Station & 16.93 & 67.84 & 3545 & 3039 \\
5 & SAST & Southern Arabian Sea Trap Station & 11.60 & 66.08 & 4243 & 3032 \\
6 & EIOT & Equatorial Indian Ocean Trap Station & 3.56 & 77.78 & 3400 & 2374 \\
7 & NBBT-N & Northern Bay of Bengal Trap Station - North & 17.42 & 89.65 & 2267 & 1889 \\
8 & NBBT-S & Northern Bay of Bengal Trap Station - South & 15.48 & 89.45 & 2709 & 2172 \\
9 & CBBT-N & Central Bay of Bengal Trap Station - North & 13.14 & 84.41 & 3266 & 2261 \\
10 & CBBT-S & Central Bay of Bengal Trap Station - South & 11.03 & 84.43 & 3462 & 2527 \\
11 & SBBT & Southern Bay of Bengal Trap Station & 5.09 & 87.26 & 3995 & 2976 \\
12 & JAM & Java Mooring & -8.28 & 108.02 & 3250 & 2456 \\
\hline
\end{tabular}

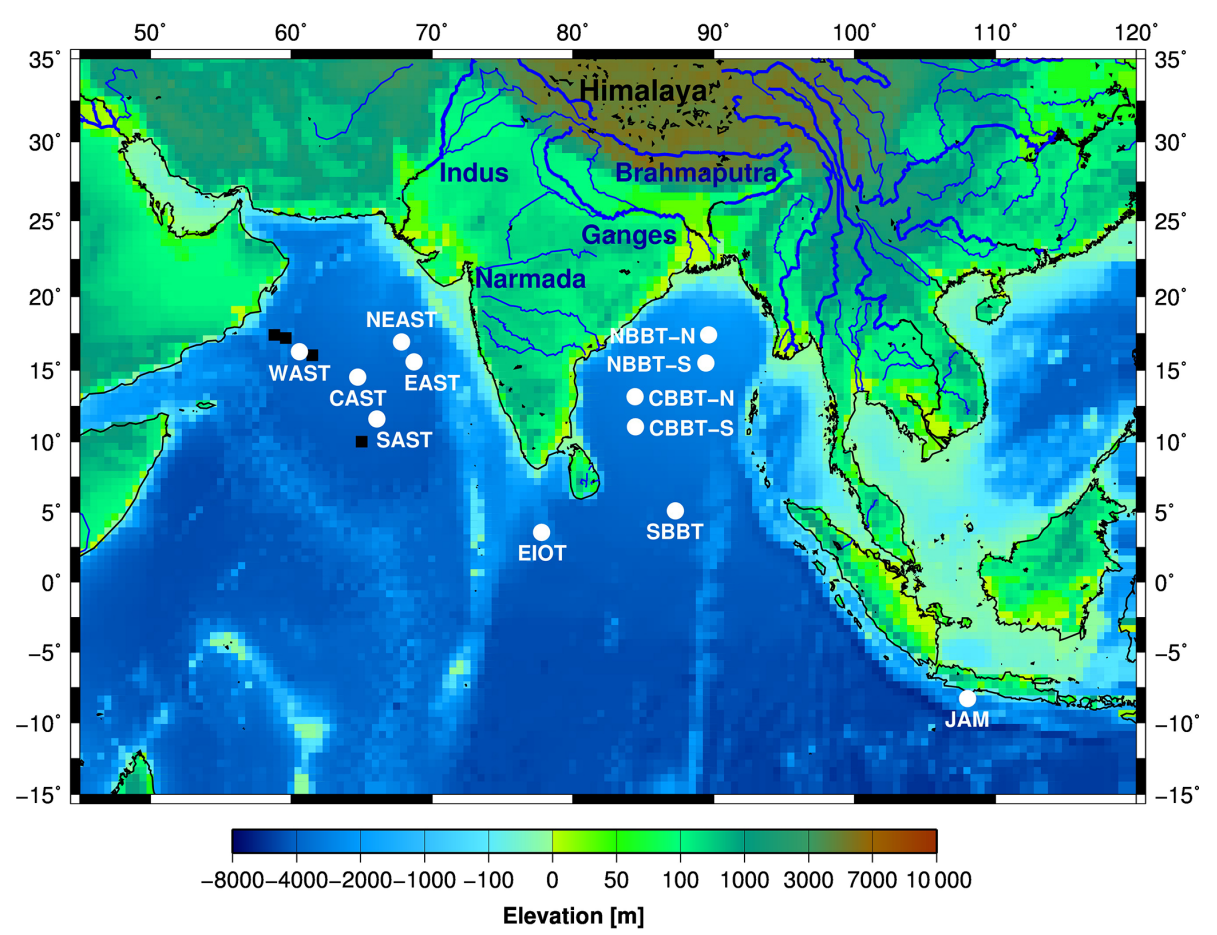

Figure 1. Bathymetric chart of the northern Indian Ocean and the adjacent land mass. Data were obtained from http://ingrid.ldeo.columbia. edu/SOURCES/WORLDBATH/ (last access: 23 September 2009). White circles show the sediment trap sites operated by the joint IndoGerman and Indonesian-German projects (see Table 1). The black circles represent the US JGOFS sediment trap sites M2 to M5 (Honjo et al., 1999; Lee et al., 1998).

bian Sea during the boreal summer (Susanto et al., 2001). Off Java and Bali this is actually the winter season, but in order to avoid confusion we use the terms "summer" and "winter" to refer to the boreal summer and winter only.

The monsoon rains feed one of the world's largest river systems (Ganges-Brahmaputra-Meghna), which originates in the Himalayas and has its maximum discharge into the Bay of Bengal in summer (Ludwig et al., 1996; Milliman and Meade, 1983; Milliman et al., 1984; Subramanian et al.,
1985). Unlike the Indian subcontinent, Indonesia has no major rivers because it comprises relatively small islands. Nevertheless, model studies suggest that the small Indonesian rivers contribute $\sim 11 \%\left(4.26 \times 10^{12} \mathrm{~m}^{3} \mathrm{yr}^{-1}\right)$ to the global freshwater discharge into the ocean (Syvitski et al., 2005). Due to the high freshwater inputs, low-salinity surface waters (salinity <33) fringe the continental shelves and margins in the eastern Indian Ocean, and the high-salinity waters 

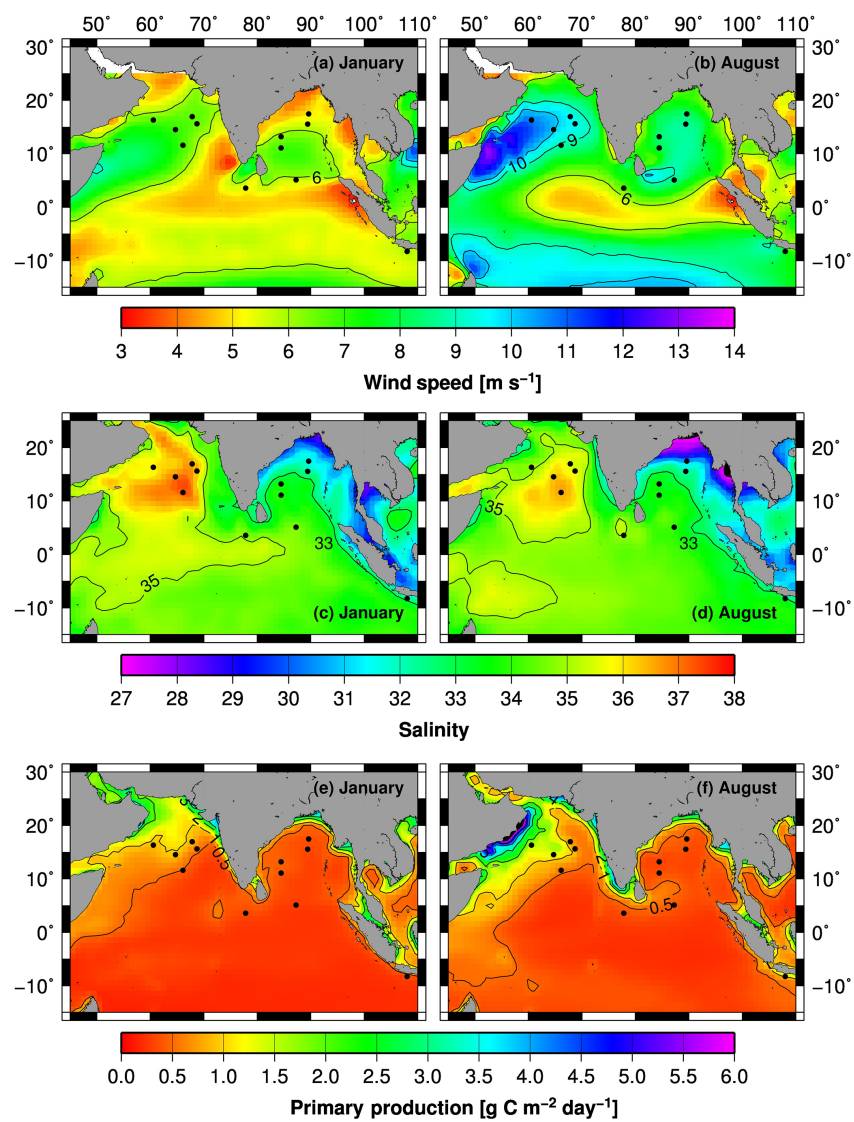

Figure 2. Monthly mean wind speeds $(\mathbf{a}, \mathbf{b})$ derived from the Scatterometer Climatology of Ocean Winds (Risien and Chelton, 2008) indicating the Findlater jet during the summer (August) in the Arabian Sea. Monthly mean sea surface salinities (c, d) derived from the Soil Moisture and Ocean Salinity (SMOS) satellite mission. Monthly mean primary production rates (Behrenfeld and Falkowski, 1997) covering the periods between 2002 and 2014 (e, f). The black circles show the sediment trap sites (Fig. 1, Table 1).

(salinity $>35$ ) reflect the negative freshwater balance in the Arabian Sea (Fig. 2c, d).

Inputs of suspended sediments from the GangesBrahmaputra-Meghna (1060 $\mathrm{Mt} \mathrm{yr}^{-1}$ ) and Indonesian rivers $\left(1630 \mathrm{Mt} \mathrm{yr}^{-1}\right)$ represent $80 \%$ and $20 \%$ of the suspended sediment inputs into the Indian and the world's ocean, respectively (Milliman and Farnsworth, 2011; Syvitski et al., 2005). Sediment discharge from the Indus into the Arabian Sea only amounts to about $10 \mathrm{Mt} \mathrm{yr}^{-1}$ (Milliman and Farnsworth, 2011) that is to a large extent trapped on the continental shelf and upper continental slope of the Indian margin due to the prevailing current regime (Ramaswamy et al., 1991). In the western part of the Arabian Sea, where the formation of high-salinity Arabian seawater (Rochford, 1966; Tchernia, 1980; Tegen and Fung, 1995) shows negligible freshwater inputs (Fig. 2c, d), eolian dust inputs are the main sources of lithogenic matter (Clemens et al., 1991; Sirocko et al., 1993; Tegen and Fung, 1995).

\section{Methods}

\subsection{Sediment trap data}

Sediment trap experiments started in 1986 in the Arabian Sea and were expanded into the Bay of Bengal in 1987. The fieldwork ended around 1998, was briefly re-initiated in 2007 and 2008 , and then aborted for safety reasons. The sediment trap moorings equipped with Mark 6 and 7 time series sediment traps were deployed for periods of 6 months to 1 year with sampling intervals of mostly around 21 days. The sediment trap sites in the northern and central Bay of Bengal were shifted slightly southward in some years so that the stations NBBT and CBBT were split into northern (NBBT-N, CBBTN) and southern sites (NBBT-S, CBBT-S; Fig. 1, Table 1). Haake et al. (1993) and Rixen et al. (1996) describe the sample processing and the analysis of bulk components (organic carbon, carbonate, biogenic opal and lithogenic matter) in detail. Organic carbon fluxes (POC) multiplied by 1.8 yield organic matter $(\mathrm{OM})$ fluxes. The lithogenic matter fluxes represent the difference between total flux and fluxes of OM, carbonate and biogenic opal. Fluxes were used to calculate monthly (Fig. 3), seasonal (Table 2), annual (Table 3) and long-term annual means (Tables 3, 4). The seasons considered were summer (June-September), winter (January-April) and transition periods (May and October to December). Annual means were calculated only when particle fluxes were measured for more than 255 days $\mathrm{yr}^{-1}$ (Table 3). Since our record at station NEAST covers only one season, we calculated a seasonal mean (Table 2), but no annual mean.

\subsection{Satellite data}

Monthly mean wind speeds and salinity data were derived from the Scatterometer Climatology of Ocean Winds (Risien and Chelton, 2008) and the Soil Moisture and Ocean Salinity (SMOS) satellite mission, respectively (Fig. 2a-d). The SMOS data covering the period between 2010 and 2012 were downloaded from ftp://ftp-icdc.cen.uni-hamburg.de/smos_ sss/ (last access: 23 March 2013). Monthly mean satellitederived sea surface temperatures (SSTs; Smith et al., 2008) were obtained from ftp://ftp.emc.ncep.noaa.gov/cmb/sst/ oimonth_v2/ASCII_UPDATE (last access: 27 March 2015). Primary production rates (PP; Fig. 2e, f) derived from the Vertically Generalized Production Model (VGPM; Behrenfeld and Falkowski, 1997) were downloaded from http: //www.science.oregonstate.edu/ocean.productivity (last access: 9 March 2015) and averaged at around $1^{\circ}$ around the trap location, as were the SST data. 
Table 2. Trap ID, season, seasonal averaged primary production, sea surface temperature, organic carbon flux and lithogenic matter content.

\begin{tabular}{|c|c|c|c|c|c|}
\hline Trap ID & Season & $\begin{array}{r}\text { PP } \\
\left(\mathrm{g} \mathrm{m}^{-2} \mathrm{day}^{-1}\right)\end{array}$ & $\begin{array}{l}\mathrm{SST} \\
\left({ }^{\circ} \mathrm{C}\right)\end{array}$ & $\begin{array}{r}\text { POC } \\
\left(\mathrm{mg} \mathrm{m}^{-2} \mathrm{day}^{-1}\right)\end{array}$ & $\begin{array}{r}\text { Lith. matter } \\
(\%)\end{array}$ \\
\hline WAST & summer & 1.28 & 25.60 & 11.69 & 14.46 \\
\hline WAST & winter & 0.79 & 26.32 & 7.50 & 15.39 \\
\hline WAST & transition & 0.49 & 27.90 & 6.48 & 13.04 \\
\hline CAST & summer & 1.11 & 26.76 & 6.95 & 16.73 \\
\hline CAST & winter & 0.70 & 26.93 & 6.41 & 14.55 \\
\hline CAST & transition & 0.42 & 28.32 & 5.52 & 15.85 \\
\hline EAST & summer & 0.57 & 27.56 & 6.82 & 21.39 \\
\hline EAST & winter & 0.46 & 27.41 & 5.28 & 19.91 \\
\hline EAST & transition & 0.30 & 28.63 & 5.05 & 21.97 \\
\hline SAST & summer & 0.56 & 27.78 & 6.65 & 14.21 \\
\hline SAST & winter & 0.34 & 27.98 & 6.46 & 15.75 \\
\hline SAST & transition & 0.30 & 28.75 & 3.91 & 14.87 \\
\hline SBBT & summer & 0.39 & 28.39 & 7.91 & 15.04 \\
\hline SBBT & winter & 0.27 & 29.00 & 5.34 & 17.48 \\
\hline SBBT & transition & 0.29 & 28.85 & 5.29 & 15.27 \\
\hline EIOT & summer & 0.38 & 28.75 & 4.55 & 10.13 \\
\hline EIOT & winter & 0.27 & 29.06 & 3.90 & 18.50 \\
\hline EIOT & transition & 0.34 & 28.92 & 4.07 & 11.65 \\
\hline CBBT-N & summer & 0.31 & 28.98 & 8.03 & 38.90 \\
\hline CBBT-N & winter & 0.32 & 27.90 & 8.00 & 36.14 \\
\hline CBBT-N & transition & 0.29 & 28.92 & 7.64 & 44.89 \\
\hline CBBT-S & summer & 0.35 & 28.95 & 5.13 & 24.33 \\
\hline CBBT-S & winter & 0.30 & 28.16 & 5.15 & 32.45 \\
\hline CBBT-S & transition & 0.30 & 28.97 & 6.19 & 21.99 \\
\hline NBBT-N & summer & 0.39 & 28.82 & 9.74 & 41.99 \\
\hline NBBT-N & winter & 0.34 & 27.15 & 7.05 & 38.06 \\
\hline NBBT-N & transition & 0.29 & 28.80 & 6.92 & 38.98 \\
\hline NBBT-S & summer & 0.34 & 28.73 & 5.91 & 32.39 \\
\hline NBBT-S & winter & 0.30 & 27.53 & 6.03 & 33.49 \\
\hline NBBT & transition & 0.27 & 28.93 & 6.17 & 32.76 \\
\hline JAM & summer & 0.86 & 27.09 & 14.35 & 60.48 \\
\hline JAM & winter & 0.31 & 29.08 & 11.47 & 68.09 \\
\hline JAM & transition & 0.49 & 28.48 & 11.75 & 60.36 \\
\hline NEAST & transition & 0.33 & 28.13 & 8.80 & 29.82 \\
\hline
\end{tabular}

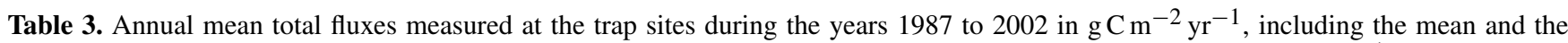
standard deviation as well as the number of years (no.) in which particle fluxes were measured for more than $255 \mathrm{days}^{-1}$. For calculating the long-term average, data obtained in years in which fluxes were measured for fewer than 255 days were omitted.

\begin{tabular}{|c|c|c|c|c|c|c|c|c|c|c|c|c|c|c|c|c|c|}
\hline \multirow[t]{2}{*}{ Trap ID } & 87 & 88 & 89 & 90 & 91 & 92 & 93 & 94 & 95 & 96 & 97 & 98 & 1 & 2 & Mean & \multirow{2}{*}{$\begin{array}{l}\text { SD } \\
(\%)\end{array}$} & \multirow[t]{2}{*}{ No. } \\
\hline & \multicolumn{15}{|c|}{$\left(\mathrm{gCm}^{-2} \mathrm{yr}^{-1}\right)$} & & \\
\hline WAST & 43.0 & 53.6 & & 66.0 & 50.6 & 48.5 & & 52.9 & 58.6 & & 69.2 & & & & 55.3 & 16.0 & 8 \\
\hline CAST & 34.4 & 40.7 & & & & & 35.0 & 40.3 & & 40.0 & & & & & 38.1 & 8.2 & 5 \\
\hline EAST & & & 39.0 & & 37.5 & & 23.3 & & & & & & & & 33.3 & 26.1 & 3 \\
\hline SAST & & & & & & & & & & & & & & & & & \\
\hline EIOT & & & & & & & & & & 21.3 & & & & & 21.3 & & 1 \\
\hline NBBT-N & & 53.2 & 50.2 & & & & & 53.4 & & 47.5 & 38.9 & 46.1 & & & 48.2 & 11.3 & 6 \\
\hline NBBT-S & & & & & 33.4 & 34.0 & & & & & & & & & 33.7 & 1.3 & 2 \\
\hline CBBT-N & & 43.5 & 56.7 & 66.4 & 60.7 & & 44.8 & & & & & & & & 54.4 & 18.3 & 5 \\
\hline CBBT-S & & & & & & 34.8 & & & & & & & & & 34.8 & & 1 \\
\hline SBBT & & 39.9 & & & 37.3 & & 37.2 & 42.3 & & & & & & & 39.9 & 6.2 & 4 \\
\hline JAM & & & & & & & & & & & & & 101.8 & 122.1 & 112.0 & 12.8 & 2 \\
\hline
\end{tabular}


Table 4. Trap ID, mean bulk fluxes including standard deviation (SD) and contents. In contrast to averages presented in Table 3, all data, including those measured in years in which fluxes were measured for fewer than 255 days, were used to calculate mean values and the standard deviations shown in this table.

\begin{tabular}{|c|c|c|c|c|c|c|c|c|c|c|c|c|}
\hline \multirow[t]{2}{*}{ Trap ID } & POC & SD & Carb. & SD & Opal & SD & Lith. & SD & POC & Carb. & Opal & Lith. \\
\hline & \multicolumn{8}{|c|}{$\left(\mathrm{g} \mathrm{m}^{-2} \mathrm{yr}^{-1}\right)$} & \multicolumn{4}{|c|}{$(\%)$} \\
\hline WAST & 3.1 & 0.4 & 29.0 & 3.5 & 13.1 & 3.9 & 7.9 & 1.5 & 5.6 & 52.3 & 23.5 & 14.2 \\
\hline CAST & 2.3 & 0.2 & 22.4 & 1.3 & 4. & 0.4 & 5.9 & 0.8 & 6.1 & 0.1 & & 15.9 \\
\hline EAST & 2.1 & 0.3 & 17.9 & 2.1 & 5.4 & 1.1 & 7.3 & 1.1 & 6.1 & 52.2 & 15.8 & 21.1 \\
\hline SAST & 3 & 0.0 & .1 & 0.0 & 0.0 & 0 & 6. & 0.0 & 5.2 & 62.0 & 13.6 & 15.0 \\
\hline EIOT & 1.5 & 0.3 & 16.4 & 3.1 & 5. & 1.5 & 3.6 & 0.9 & 5.4 & 58.7 & 18.7 & 12.8 \\
\hline NBBT-I & 2.9 & 0.3 & 13.3 & 1.9 & 10.4 & 0.7 & 18.8 & 3.9 & 6.1 & 27.9 & 21.8 & 39.5 \\
\hline NBBT-S & 2.2 & 0.0 & 11.0 & 0.4 & 7.7 & 0.4 & 11.1 & 0.3 & 6.5 & 32.5 & 22.9 & 32.9 \\
\hline CBBT-N & 2.9 & 0.3 & 15.5 & 1.0 & 11.7 & 2.3 & 21.9 & 5.9 & 5.3 & 28.5 & 21.6 & 40.3 \\
\hline CBBT- & & 0.0 & & 0. & & 0 & 9.0 & 0 & & 38.4 & 25.6 & 25.7 \\
\hline SBBT & 2 & 0.3 & 0 & 1.8 & 9.8 & 1.5 & 6.1 & 1 & 5.6 & 50.0 & 24.6 & 15.3 \\
\hline JAM & 4.8 & 0.6 & 15.1 & 2.5 & 31.3 & 15.6 & 86.6 & 23.9 & 3.4 & 10.7 & 22.1 & 61.1 \\
\hline
\end{tabular}
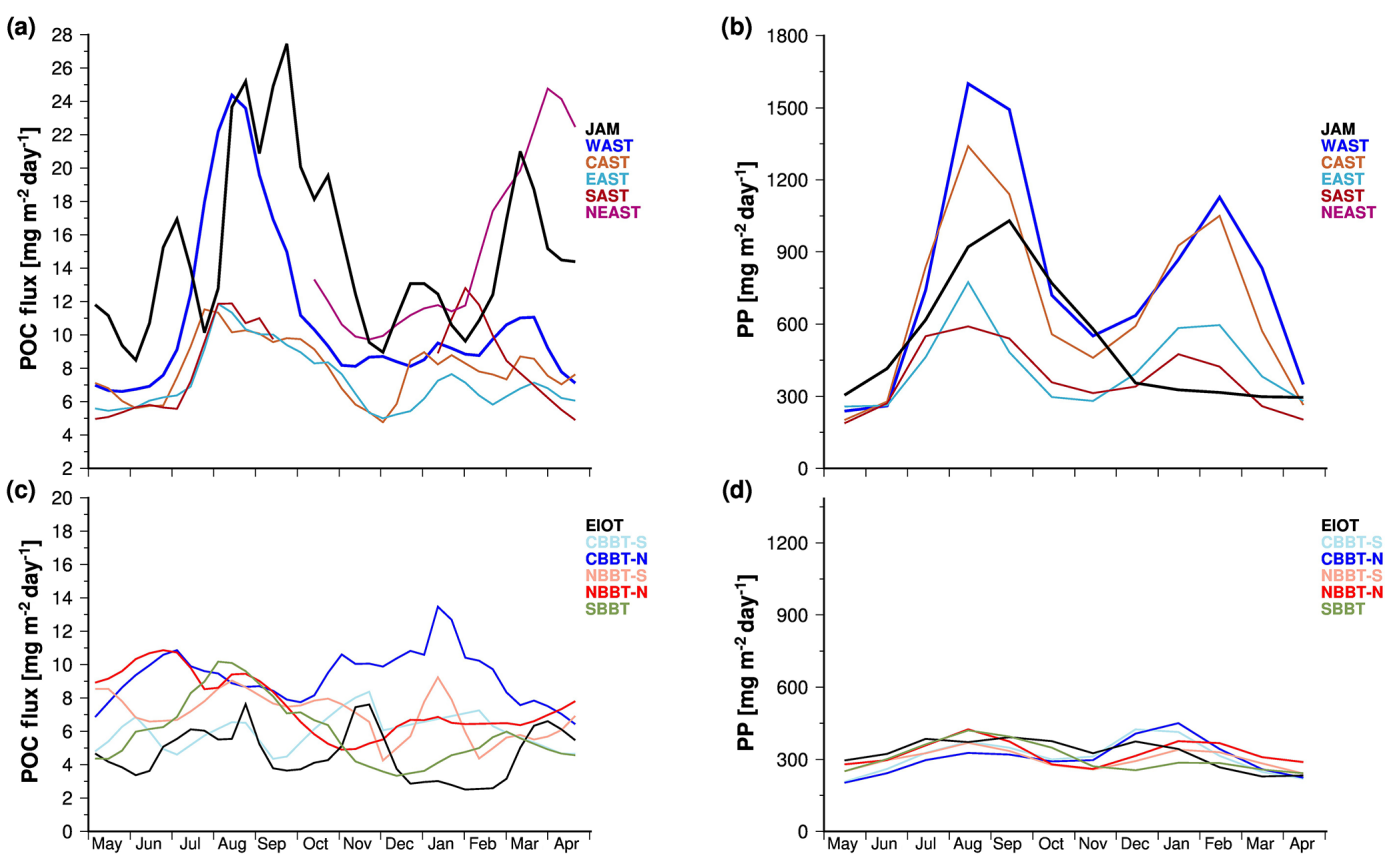

Figure 3. Monthly mean organic carbon fluxes (POC) obtained from our sediment trap experiments in the Arabian Sea (a) and the Bay of Bengal (c) as well as monthly mean primary production rates (Behrenfeld and Falkowski, 1997) selected for the sediment trap sites (b, d). The sediment trap data were normalised to a water depth of $2000 \mathrm{~m}$ by using the equation introduced by Rixen et al. (2002).

Equations (1)-(3) introduced by Eppley and Peterson (1979), Laws et al. (2000) and Henson et al. (2011) were used to convert primary into export production ( $\left.\mathrm{POC}_{\text {Export }}\right)$.

$$
\begin{aligned}
& E: \mathrm{POC}_{\text {Export }}=0.5 \cdot 0.025 \cdot \mathrm{PP}^{2} \rightarrow \mathrm{PP}>200 \\
& L: \mathrm{POC}_{\text {Export }}=(-0.02 \cdot \mathrm{SST}+0.63) \cdot \mathrm{PP} \\
& H: \mathrm{POC}_{\text {Export }}=0.23 \cdot \exp ^{(-0.08 \cdot \mathrm{SST})} \cdot \mathrm{PP}
\end{aligned}
$$

We applied Eqs. (1)-(3) to the satellite-derived primary production rates to calculate export production. Eppley and Peterson (1979) suggested two different equations for PP less than and more than $200 \mathrm{~g} \mathrm{~m}^{-2} \mathrm{yr}^{-1}$. The monthly mean primary and export production rates covering the period between 2002 and 2015 were used to calculate monthly (Fig. 3), seasonal (Table 2) and long-term annual means (Table 5).

\subsection{Multiple linear regression (MLR) analysis}

A multiple linear regression analysis was applied to calculate carrying coefficients $(f)$. Here, we used the OLS regression 


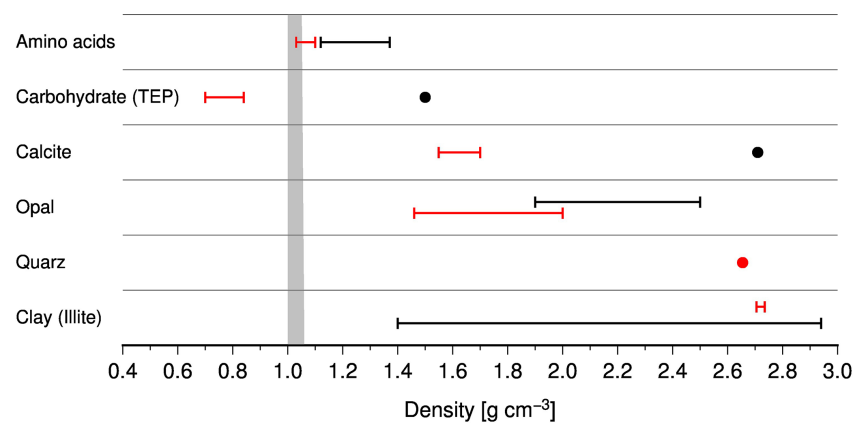

Figure 4. Densities of bulk components including quartz and illite as representatives of lithogenic matter (red lines and circle). Black circles and lines indicate the densities of crystalline analogues and of cellulose as an example of a carbohydrate. The data were compiled from the literature and the references are given in the text. The grey area shows the density range of seawater.

analysis included in the Python module statsmodels.

$$
\begin{aligned}
& F_{\text {POC }}\left[\frac{g}{\mathrm{~m}^{2} \cdot \mathrm{yr}}\right]=\left(f_{\text {Lith. }} \cdot F_{\text {Lith. }}\right)+\left(f_{\text {Opal }} \cdot F_{\text {Opal }}\right) \\
& \quad+\left(f_{\text {Carb. }} \cdot F_{\text {Carb. }}\right)
\end{aligned}
$$

$F$ represents fluxes of the respective bulk component lithogenic matter (Lith.), biogenic opal (Opal) and carbonate (Carb.). In order to estimate the relative importance of individual ballast minerals (RIB) for the POC flux $\left(F_{\mathrm{POC}}\right)$, their contribution to the predicted POC flux was calculated:

$\mathrm{RIB}_{i}[\%]=\frac{100}{F_{\mathrm{POC}}} \cdot\left(f_{i} \cdot F_{i}\right)$,

where $i$ indicates the different ballast minerals.

\subsection{Sinking speed}

The influence of the individual ballast minerals can also be derived from a more mechanistic approach by quantifying their contribution to the density of the solids ( $\left.\rho_{\text {solids }}\right)$.

$\rho_{\text {solids }}=\frac{\left\{\begin{array}{c}\left(\mathrm{Lith} \% \cdot D_{\text {lith }}\right)+\left(\mathrm{OM} \% \cdot D_{\mathrm{OM}}\right) \\ +\left(\mathrm{Opal} \% \cdot D_{\text {Opal }}\right)+\left(\mathrm{Carb} \% \cdot D_{\text {Carb. }}\right)\end{array}\right\}}{100}$

Lith \%, OM $(=\mathrm{POC} \times 1.8) \%$, Opal \% and Carb \% are the percentage of the respective ballast minerals in the sinking particles collected in the sediment traps and $D$ represents their density in $\mathrm{g} \mathrm{cm}^{-3}$.

Densities of the bulk component show a wide range and fall below those of their crystalline analogues (Fig. 4). For example, the density of proteins varies between 1.22 and $1.47 \mathrm{~g} \mathrm{~cm}^{-3}$, whereas the density of organic matter in phytoplankton comprising $>80 \%$ of amino acids varies between 1.03 and $1.1 \mathrm{~g} \mathrm{~cm}^{-3}$ (Lee et al., 2004; Logan and Hunt, 1987; Miklasz and Denny, 2010; Quillin and Matthews, 2000).
With $0.7-0.84 \mathrm{~g} \mathrm{~cm}^{-3}$, the density of transparent exopolymers (TEPs), which play an essential role for the formation of marine snow, is even below that of seawater (Azetsu-Scott et al., 2004). Other carbohydrates such as cellulose have a density of $1.5 \mathrm{~g} \mathrm{~cm}^{-3}$. The density of calcite - the most common calcium carbonate mineral in the pelagic ocean - is $2.71 \mathrm{~g} \mathrm{~cm}^{-3}$ (Mottana et al., 1978). In turn, coccolithophores and foraminifera tests reveal densities of only $1.55 \mathrm{~g} \mathrm{~cm}^{-3}$ (Winter and Siesser, 1994) and up to $1.7 \mathrm{~g} \mathrm{~cm}^{-3}$ (Schiebel et al., 2007; Schiebel and Hemleben, 2000). In contrast to opal, which is a hydrous silicon oxide with a density between 1.9 and $2.5 \mathrm{~g} \mathrm{~cm}^{-3}$, the density of diatom frustules (biogenic opal) varies between 1.46 and $2.0 \mathrm{~g} \mathrm{~cm}^{-3}$ (Csögör et al., 1999; DeMaster, 2003).

The density of lithogenic matter depends on its mineral composition. Clay minerals change their density by adsorbing water, which is most pronounced within the group of smectites. Their density decreases from 2.72 to $1.4 \mathrm{~g} \mathrm{~cm}^{-3}$ during hydration (Osipov, 2012), whereas hydration hardly affects the density of illite, which decreases from 2.75 to $2.72 \mathrm{~g} \mathrm{~cm}^{-3}$. At our trap sites, illite and quartz dominate lithogenic matter (Ramaswamy et al., 1991, 1997). Since the density of quartz is $2.65 \mathrm{~g} \mathrm{~cm}^{-3}$, we assumed a density of $2.70 \pm 0.05 \mathrm{~g} \mathrm{~cm}^{-3}$ for lithogenic matter at our trap sites. Accordingly, we used a density of $2.70 \pm 0.05,0.9 \pm 0.2$, $1.73 \pm 0.27$ and $1.63 \pm 0.08$ for lithogenic matter, organic matter, biogenic opal and carbonate, respectively, to calculate the densities of the solids and sinking speeds of particles (Table 6).

The density of solids is the term describing the effect of mineral particles on the sinking speed of particles in Stokes' law. Stokes' law is derived from the Navier-Stokes equation and a commonly used parameterisation for calculating the sinking velocity $(U)$ of particles (e.g. Engel et al., 2009; Lal and Lerman, 1975; McCave, 1975; Miklasz and Denny, 2010):

$U=\frac{\left(2 \cdot g \cdot \Delta \rho \cdot \text { radius }^{2}\right)}{9 \eta}$,

where $g$ is the gravitational acceleration and (radius) defines the radius of the sinking particle; $\eta$ is the viscosity and $\Delta \rho$ represents the excess density of particles over water or - expressed in other words - the difference between the density of the particle $\left(\rho_{\text {particle }}\right)$ and seawater $\left(\rho_{\text {seawater }}\right)$.

$\Delta \rho=\rho_{\text {particle }}-\rho_{\text {seawater }}$

The density of a sinking particle results from its pore water content and the density of the solids.

$\rho_{\text {particle }}=\left(\right.$ porosity $\left.\cdot \rho_{\text {water }}\right)+(1-$ porosity $) \cdot \rho_{\text {solids }}$

Sinking speed $(U)$ can be used to estimate the organic carbon flux (POC) at trap depth $z$ according to Eq. (10) introduced by Banse (1990):

$\operatorname{POC}(z)=\operatorname{POC}_{\text {Export }} \cdot e^{\left[\frac{-\lambda \cdot(z-\text { depth of the euphotic zone })}{\text { sinking speed }}\right]}$, 
where $\lambda$ is the POC-specific respiration rate and $\left(\mathrm{POC}_{\text {Export }}\right)$ is the export production; $\lambda$ was assumed to vary in a relatively narrow range $\left(0.106 \pm 0.028 \mathrm{day}^{-1}\right.$; Iversen and Ploug, 2010; Ploug and Grossart, 2000), whereas more recent studies suggest that $\lambda$ decreases with decreasing temperatures (Iversen and Ploug, 2013; Marsay et al., 2015). Direct field observations are scarce (Laufkötter et al., 2017) but in situ incubation experiments carried out at a water depth of $<500 \mathrm{~m}$ indicate respiration rates of $0.4 \pm 0.1$ and $0.01 \pm 0.02 \mathrm{day}^{-1}$ in the subtropical North Atlantic Ocean and the Southern Ocean, respectively (McDonnell et al., 2015). We selected a $\lambda$ of 0.106 day $^{-1}$, which is well within this range.

The viscosity of the fluid $(\eta)$ and the density of seawater ( $\rho_{\text {water }}$ ) were calculated as a function of seawater temperature and salinity by using the Python routines GSW (Gibbs SeaWater) and IAPWS (International Association for the Properties of Water and Steam) (IOC et al., 2010; Wagner and Pruß, 2002). Seawater temperature and salinity were selected from the World Ocean Atlas 2013 (Locarnini et al., 2013; Zweng et al., 2013) for each trap site (Fig. 5a, b) and averaged between water depths of 100 and $1500 \mathrm{~m}$ (Table 5). At our sediment trap sites, the porosity of particles and the radius are unknown. Based on results derived from other studies, we assume a porosity of 0.917 (Logan and Hunt, 1987).

The equivalent spherical diameters (ESDs) of sinking particles cover a wide size spectrum ranging mostly between 0.01 and $<5 \mathrm{~mm}$ (Guidi et al., 2009; Iversen et al., 2010). Diameters of particles formed in rolling tanks, which often exceed $1 \mathrm{~mm}$, reached ESDs of $>1 \mathrm{~cm}$ and resemble in size marine snow collected by scuba divers in the surface water of the ocean that have ESDs of up to $7.5 \mathrm{~cm}$ (Alldredge and Gotschalk, 1988; Engel et al., 2009). An ESD of $0.1 \mathrm{~mm}$ is a commonly considered threshold dividing small and large particles (Durkin et al., 2015; Guidi et al., 2009). We selected an ESD of $0.15 \mathrm{~mm}$ to calculate sinking speeds (Table 6, Fig. 5c).

\section{Results and discussion}

\subsection{Interannual variability}

The interannual variability of particle fluxes was largest at EAST (Table 3). At this site we intercepted particle fluxes over periods of $>255$ days per year during 3 years. In 1989 and 1991 fluxes hardly deviate from each other, but total fluxes dropped by $40 \%$ in 1993. In contrast to EAST, where our record covers only 3 years, the record of particle fluxes at four sites in the northern Indian Ocean extends over a period of 5 or more years. Two of theses sites were in the Arabian Sea (WAST and CAST) and two were in the Bay of Bengal (NBBT-N and CBBT-N). Among these sites the annual mean fluxes revealed a standard deviation of $<18.3 \%$.

Sediment traps are the only, and thus the most intensively used, tool to measure the seasonal and interannual variability of particle fluxes in the ocean (Turner, 2015), but hydrodynamic, biological and chemical processes bias the accuracy of sediment trap measurements (e.g. Antia, 2005; Buesseler et al., 2007). Since current velocities decrease with depth and zooplankton migration is restricted to water depth $<900 \mathrm{~m}$, particle fluxes measured at water depth $>1500 \mathrm{~m}$ are generally considered the most reliable (Bianchi et al., 2013; Honjo et al., 2008). Nevertheless, there are indications that deepmoored traps can also undertrap organic matter fluxes by $60 \%$ (Buesseler et al., 1992, 2007; Usbeck et al., 2003; Yu et al., 2001). Radionuclide studies on samples collected during the first year of the sediment trap experiment in the Arabian Sea revealed trapping efficiencies ranging between 0.89 and 1.17 at WAST and CAST; trapping efficiencies at EAST of 1.14 to 1.37 indicated an overtrapping (Yu et al., 2001). Such changes of the trapping efficiency may be a prime reason underlying the observed interannual variability of particle fluxes, which is generally low (Table 3 ).

\subsection{Seasonality}

The biases inherent in the method are too weak to mask the influence of monsoon-driven processes on organic fluxes on a seasonal timescale. In comparison to interannual variability the sediment trap data showed a pronounced seasonality with enhanced fluxes during boreal summer in the Arabian Sea and at JAM off southern Java (Fig. 3a). Between May and August-September organic carbon fluxes increased from approximately 7 and $10 \mathrm{mg} \mathrm{m}^{-2} \mathrm{day}^{-1}$ to about 24 and $26 \mathrm{mg} \mathrm{m}^{-2} \mathrm{day}^{-1}$. This represents an increase of about $240 \%$ and $160 \%$ at stations WAST and JAM, respectively, and exceeds estimated impacts of a changing trapping efficiency on the organic carbon fluxes. This also applies to the other sites in the Arabian Sea where organic carbon fluxes increased by about $100 \%$ (from $\sim 6$ to $\sim 12 \mathrm{mg} \mathrm{m}^{-2}$ day $^{-1}$ ) between May and August. However, in the Arabian Sea winter peaks were less pronounced compared to summer maxima, except at the trap site NEAST (Fig. 3a). Although the record at this site covered not even a full year, it recorded an increase in organic carbon fluxes by $160 \%$ from 10 to $26 \mathrm{mg} \mathrm{m}^{-2}$ day $^{-1}$ between November and March, suggesting a seasonal response of organic carbon fluxes to the winter monsoon that weakened towards the south and southwest. In the Bay of Bengal and at EIOT in the equatorial Indian Ocean the seasonality of organic carbon fluxes was weaker than in the Arabian Sea and specific responses of the organic carbon fluxes to summer and winter monsoon forcing are lacking (Fig. 3c). Importantly, however, the seasonality of organic carbon fluxes in the Arabian Sea and at JAM (as well as the weak seasonality in the Bay of Bengal) reflects the impacts of the monsoons on surface ocean processes (e.g. Ittekkot et al., 1991; Rixen et al., 2009).

The monsoon is thought to cause seasonality through its impact on the physical nutrient supply mechanisms, such as upwelling, vertical mixing and river discharges. River- 


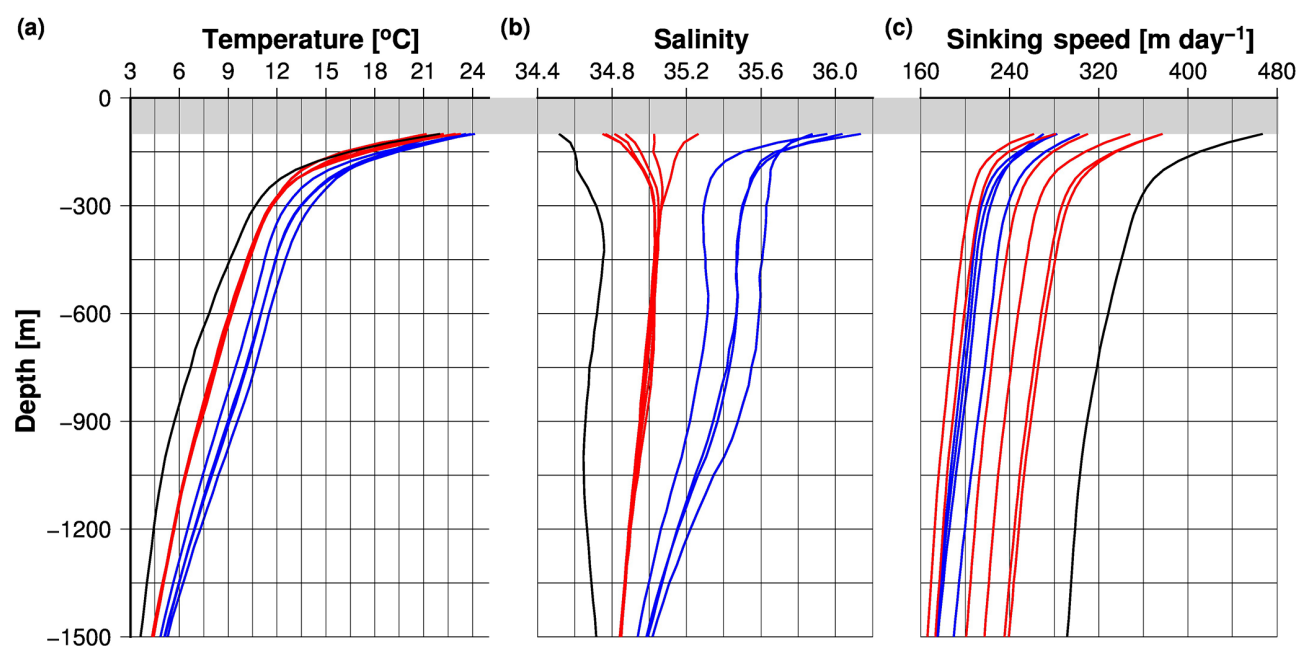

Figure 5. Seawater temperature (a) and salinity profiles (b) selected from the World Ocean Atlas 2013 for the trap site. (c) Speed of sinking material derived from the seawater properties (Eqs. 7-9) and the density of the solid (see Eq. 6). The grey bar indicates a water depth of $<100 \mathrm{~m}$. Black, red and blue lines represent the trap site JAM and the trap sites in the Bay of Bengal and the Arabian Sea.

ine nutrient discharges are assumed to increase organic carbon fluxes within river plumes near the coast, but after the consumption of nutrients within the river plume nutrientdepleted freshwater forms a buoyant low-salinity surface layer in the open Bay of Bengal (Kumar et al., 1996). This increases stratification in the surface ocean and reduces nutrient inputs during mixed layer deepening in summer and winter, which in turn weakens the seasonality of organic carbon fluxes at trap sites in the Bay of Bengal. The same occurs in the rainy season (boreal winter) off southern Java, but here riverine nutrient inputs increase organic carbon fluxes because the trap site JAM is located close to the coast (Rixen et al., 2006).

Similar to the organic carbon fluxes the monthly mean satellite-derived primary production rates at the trap sites also indicate a more pronounced seasonality at JAM and in the Arabian Sea than at the trap sites in the equatorial Indian Ocean and the Bay of Bengal (Fig. 3b, d). This pattern agrees with the well-known concept of export production being driven by inputs of nutrients from the aphotic zone and external reservoirs (the atmosphere and the land) into the euphotic zone (Dugdale and Goering, 1967; Eppley and Peterson, 1979). But the data show that organic carbon fluxes are higher at JAM than at WAST, whereas primary production is lower at JAM than at WAST. Furthermore, low primary production at JAM corresponds to enhanced organic carbon fluxes in winter, which indicates a decoupling between primary production and organic carbon fluxes at JAM, which will be explored in more detail in the following.

\subsection{The Java Mooring (JAM)}

The sediment trap data at site JAM overlap temporally with satellite observations of primary production so that these

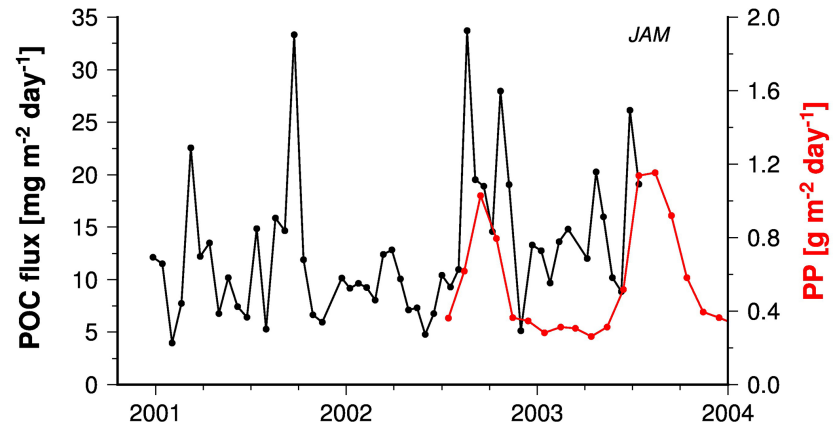

Figure 6. Organic carbon fluxes measured at JAM and the primary production rates selected for the JAM site.

records can be directly compared (Fig. 6). This comparison shows that high organic carbon fluxes during the upwelling season in summer 2002 corresponded to high primary production rates, but this was not the case during the rainy season in winter 2002-2003. The ratio between organic carbon fluxes and primary production was enhanced in winter (Figs. 3, 6) and corresponded to an increase in lithogenic matter content by about $8 \%$ between summer and winter (Table 1). There are several possible explanations for these patterns. A dense cloud cover shades the Indonesian seas from space observations and biases satellite observations of primary production, especially in winter (Hendiarti et al., 2004). On the other hand, enhanced resuspension of shelf and upper slope sediments and inputs of sediments from land during the rainy season in winter compared to the upwelling season in summer provide lithogenic matter to amplify the ballast effect and cause a decoupling of satellite-derived primary production rates and organic carbon fluxes. 
An influence of resuspended sediments has been dismissed on the basis of stable oxygen isotopes $\left(\delta^{18} \mathrm{O}\right)$ and $\mathrm{Mg} / \mathrm{Ca}$ ratios of foraminifera shells collected by the JAM trap. $\delta^{18} \mathrm{O}$ and $\mathrm{Mg} / \mathrm{Ca}$ ratios are well-known seawater temperature and salinity proxies and they were measured in shells of Globigerinoides ruber sensu stricto (s.s.) and G. ruber sensu lato (s.l.) thriving in the surface mixed layer (Mohtadi et al., 2009). The time series $\delta^{18} \mathrm{O}$ values and $\mathrm{Mg} / \mathrm{Ca}$ ratios in trap material tracked satellite-derived sea surface temperatures and the relationship between $\mathrm{Mg} / \mathrm{Ca}$ ratio and the satellitederived sea surface temperature resembled those found in other regions, arguing against significant contributions of materials resuspended from sediments.

The high lithogenic matter content of $61 \%$ (Table 4) and the vicinity of the trap site JAM to the coast of Java (Fig. 1) suggest that inputs of resuspended sediments and river discharges are a significant source of lithogenic matter and strongly influenced observed fluxes at JAM. Notably, clear fingerprints of land-derived particulate matter are freshwater diatom frustules that were encountered in the trap during the winter wet season, albeit in low numbers (Romero et al., 2009). However, organic carbon-to-nitrogen ratios and stable carbon isotopic ratios of organic matter were in the range of marine plankton, suggesting that inputs of terrestrial organic matter were negligible (Rixen et al., 2006). From these indications we infer that the high lithogenic matter environment at JAM leads to a strong ballast effect and is the reason for higher organic carbon fluxes at JAM than at WAST, despite a much lower primary production at JAM than at WAST (Fig. 3).

\subsection{Primary production and organic carbon fluxes}

To distinguish the roles of primary production and the ballast effect on the organic carbon flux, seasonal means (Table 2) were used to calculate the transfer efficiency ( $\left.T_{\text {eff }}\right)$ of organic carbon. This defines the ratio between organic carbon fluxes measured by sediment traps and export production and expresses the fraction of export production which reaches the deep sea (Francois et al., 2002). To calculate $T_{\text {eff }}$ we converted primary production into export production by using Eqs. (1) to (3). The results among the three equations differed: the lowest and highest export production rates were obtained by using Eq. (3) $\left(8-49 \mathrm{mg} \mathrm{m}^{-2}\right.$ day $\left.^{-1}\right)$ and Eq. (1) (178-639 $\left.\mathrm{mg} \mathrm{m}^{-2} \mathrm{day}^{-1}\right)$, respectively. Export production is difficult to quantify in the field and constitutes a highly uncertain element in the marine carbon cycle. The wide range of estimates of global mean export production $\left(1.8-27.5 \times 10^{15} \mathrm{~g} \mathrm{C} \mathrm{yr}^{-1}\right)$ reflects this uncertainty (del Giorgio and Duarte, 2002; Honjo et al., 2008; Lutz et al., 2007). Since we cannot resolve this issue and have no data to validate the calculated export production, we used results obtained from all three equations to compute export production rates and $T_{\text {eff }}$ (Fig. 7).
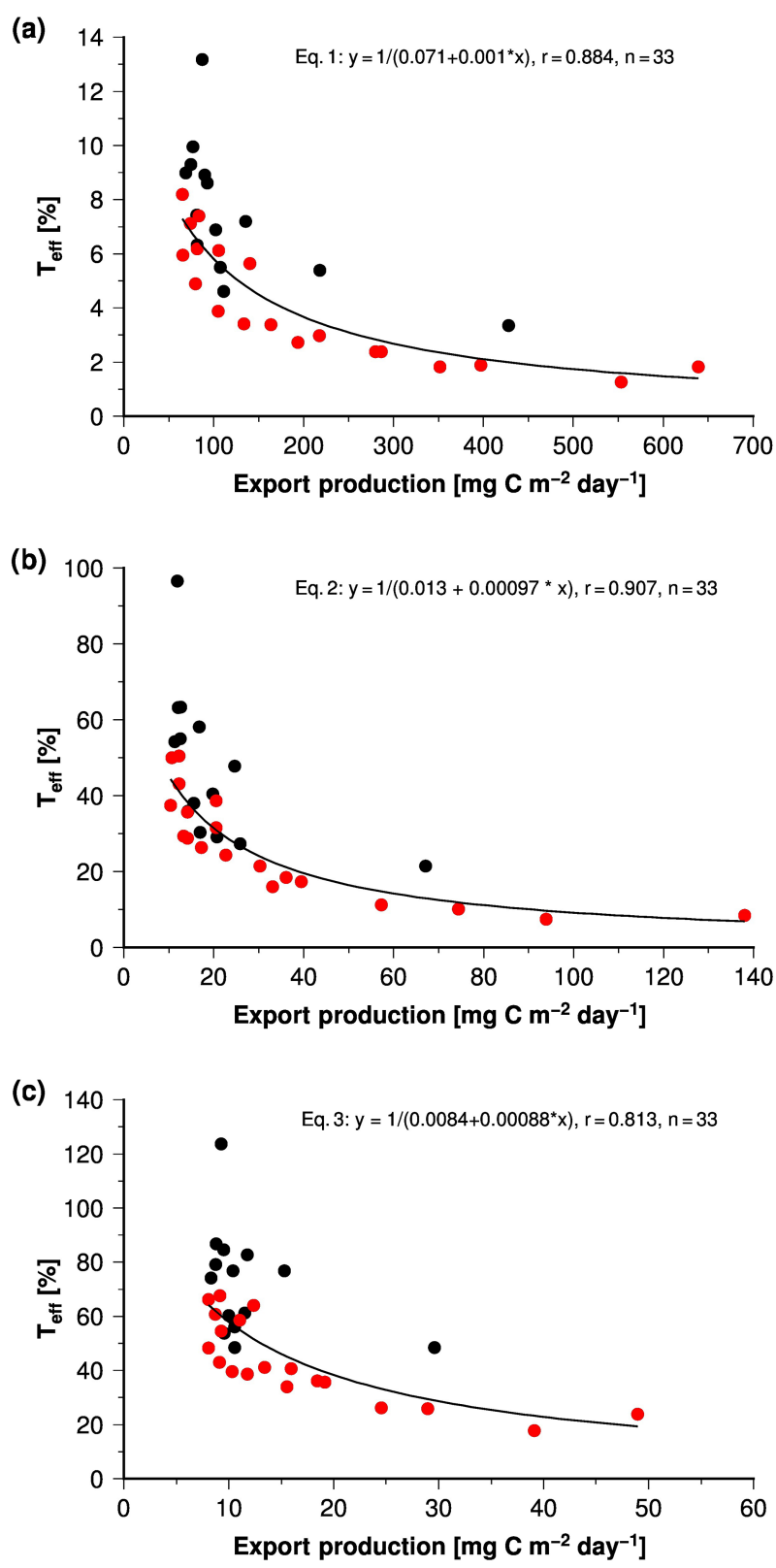

Figure 7. $T_{\text {eff }}$ versus export production rates derived from Eqs. (1) (a), (2) (b) and (3) (c). The red circles indicate samples associated with lithogenic matter content $<25 \%$.

Francois et al. (2002) calculated $T_{\text {eff }}$ by using Eq. (2) and a global compilation of sediment trap data, which also contained data from the Arabian Sea and the Bay of Bengal. Their results indicated that $9.6 \pm 4.9 \%$ and $16 \pm 2.4 \%$ of the exported organic carbon arrives in the sediment traps in the Arabian Sea and the Bay of Bengal. Using Eq. (2) as Francois et al. (2002), our annual mean data suggest that $16.5 \pm 5 \%$ and $46.5 \pm 5 \%$ of the exported organic matter reach the traps, respectively. Different SST values used to calculate export production mainly cause this deviation because Eq. (2) is extremely sensitive to temperature changes. SSTs obtained 
from Smith et al. (2008) were approximately $0.6^{\circ}$ higher than those used by Francois et al. (2002). But even with these different SST values the resulting shifts in $T_{\text {eff }}$ using Eq. (2) are small in comparison to the spread of estimates of all three equations: on average $6 \pm 3 \%$ (Eq. 1), $35 \pm 19 \%$, (Eq. 2) or $56 \pm 22 \%$ (Eq. 3) of the export production reaches the sediment traps.

Independent of the equation used, the calculated export production correlates with $T_{\text {eff }}$, and $T_{\text {eff }}$ increases with decreasing export production (Fig. 7). Francois et al. (2002) explained this with a more labile quality of organic matter exported when $f$ ratios (export / primary production) are high. A high $f$ ratio indicates a low recycling efficiency of organic matter in the euphotic zone and thus a reduced transfer of organic matter to higher trophic levels. The low recycling efficiency favours the export of more labile organic matter in marine snow, and the reduced transfer of organic matter to higher trophic levels reduces the formation of fast-sinking zooplankton faecal pellets. More labile organic matter is exported in slower-sinking marine snow, which in turn favours respiration and lowers $T_{\text {eff }}$.

If we divide our data into two groups characterised by lithogenic matter content of $<25 \%$ and $>25 \%$, the group with lithogenic matter content $>25 \%$ has generally higher $T_{\text {eff }}$ at similar export production rates (Fig. 7). This suggests that the lithogenic content increases $T_{\text {eff }}$ if lithogenic matter content exceeds $25 \%$. This is the case in samples collected in the river-dominated northern and central Bay of Bengal and at JAM. In winter $T_{\text {eff }}$ at JAM even exceeds $100 \%$ if Eq. (3) is used to calculate export production. This is unrealistic as it means that organic carbon fluxes measured by the trap exceed the calculated export production, but it points towards the strong lithogenic matter ballast effect at site JAM in winter.

\subsection{Carbonate versus lithogenic ballast}

Analysis by MLR is an approach to study the relative importance of different ballast minerals. It was applied here to test the assumption that lithogenic matter is the main ballast mineral in river-influenced regions and to investigate the roles of individual ballast minerals in organic carbon fluxes at the other trap locations in the Indian Ocean. For this investigation we included data obtained from six sediment traps deployed at water depths of $>2220 \mathrm{~m}$ in the western Arabian Sea off Oman during the US JGOFS programme in 19941995 at sites MS2-5 (Fig. 1; Honjo et al., 1999). Applied to annual means, the MLR implies that the highest carrying coefficients are associated with biogenic opal, followed by those of carbonate (Table 7). This matches results obtained by Ragueneau et al. (2006) and disagrees with those obtained from geographically weighted analyses, which identified carbonate and lithogenic matter as the main ballast minerals in the Arabian Sea and the Bay of Bengal (Wilson et al., 2012).
To discern regional differences within the Indian Ocean, the MLR was furthermore conducted on data of the bulk composition of sinking particles collected in the individual sampling cups at each sediment trap site (Table 7). This revealed that on average the highest carrying coefficients are associated with lithogenic matter. Weighting by multiplying the carrying coefficients with the associated flux (RIB) indicates that lithogenic matter ballast contributes on average $43 \pm 19 \%$ to the predicted organic carbon fluxes (Table 8), but with regional differences. At WAST the analysis suggests that carbonate is the main ballast mineral and - in contrast to our previous inference - also at JAM, which is surprising considering the low carbonate and high lithogenic matter content in samples from these two sites (Tables 4, 5). A correlation analysis of organic carbon fluxes with the content of the individual ballast materials suggests a threshold of $25 \%$ beyond which lithogenic matter content correlates with organic carbon fluxes measured in the Indian Ocean (Fig. 8a). Below this threshold in lithogenic matter content, organic carbon fluxes correlate best with carbonate fluxes and vary independent of lithogenic matter concentrations (Fig. 8b). This corroborates the role of lithogenic matter as the dominant ballast material in river-influenced regions, whereas carbonate is the main ballast mineral in other areas of the Indian Ocean (Francois et al., 2002). The correlation between carbonate and organic carbon fluxes observed here is very likely a consequence of joint production rather than of the ballast effect. For instance, in the western Arabian Sea peak fluxes of pelagic foraminifera coincide with upwelling-driven diatom blooms (Haake et al., 1993). Foraminifera tests are incorporated into and weight sinking particles, but due to their size also sink individually at velocities of several hundred metres per day (Schiebel, 2002; Schiebel and Hemleben, 2005; Schmidt et al., 2014). This contrasts with lithogenic matter that mostly consists of clay minerals (Ramaswamy et al., 1991) too small to sink on their own (Honjo, 1976; McCave, 1975; Rex and Goldberg, 1958). Clay minerals are therefore transferred into the deep sea mainly by incorporation into aggregates and faecal pellets, implying that their effect as ballast should be particularly strong in ocean areas rich in alumosilicate detritus that enhances the sinking velocity of aggregates and marine snow.

\subsection{Sinking speeds and organic carbon fluxes}

An important effect of ballast is to increase the specific density of sinking materials and to accelerate sinking velocities. Equations (6)-(9) were used to calculate sinking speeds based on seawater properties, the composition of the sinking material and the respective densities of the bulk components (Table 6). The average calculated sinking speed is $224 \pm$ $33 \mathrm{~m} \mathrm{day}^{-1}$ and agrees with sinking speeds of $>214 \mathrm{~m} \mathrm{day}^{-1}$ calculated from the time lag of about 14 days between the onset of upwelling and the associated increase in organic fluxes at a water depth of about $3000 \mathrm{~m}$ in the Arabian Sea (Rixen 
Table 5. Trap ID, annual mean primary production (PP) and sea surface temperature (SST) as well as seawater temperature (Temp.) and salinity. Temperature and salinity were selected for trap sites from the World Ocean Atlas 2013 and averaged between a water depth of 100 and $1500 \mathrm{~m}$. Density and viscosity were calculated by using temperature and salinity, considering a water depth of $800 \mathrm{~m}$. Python routines GSW and IAPWS were used for these calculations. In addition to our trap site, data for the US JGOFS trap sites MS2-5 were also selected. Figure 1 shows the location of these sites.

\begin{tabular}{lrrrrrr}
\hline Station ID & $\begin{array}{r}\text { PP } \\
\left(\mathrm{g} \mathrm{m}^{-2} \mathrm{day}^{-1}\right)\end{array}$ & $\begin{array}{r}\text { SST } \\
\left({ }^{\circ} \mathrm{C}\right)\end{array}$ & $\begin{array}{r}\text { Temp. } \\
\left({ }^{\circ} \mathrm{C}\right)\end{array}$ & Salinity & $\begin{array}{r}\text { Density } \\
\left(\mathrm{g} \mathrm{cm}^{-3}\right)\end{array}$ & $\begin{array}{r}\text { Viscosity } \\
\left(\mathrm{kg} \mathrm{m}^{-1} \mathrm{~s}^{-1}\right)\end{array}$ \\
\hline WAST & 0.79 & 26.93 & 11.48 & 35.49 & 1.030511 & 0.001217 \\
CAST & 0.69 & 27.57 & 11.22 & 35.43 & 1.030517 & 0.001225 \\
EAST & 0.42 & 28.07 & 11.11 & 35.42 & 1.030529 & 0.001229 \\
SAST & 0.38 & 28.38 & 10.63 & 35.29 & 1.030525 & 0.001244 \\
NEAST & 0.49 & 27.81 & 11.32 & 35.47 & 1.030527 & 0.001222 \\
EIOT & 0.33 & 29.05 & 9.34 & 35.01 & 1.030555 & 0.001287 \\
NBBT-N & 0.33 & 28.25 & 9.42 & 34.96 & 1.030505 & 0.001285 \\
NBBT-S & 0.30 & 28.43 & 9.42 & 34.96 & 1.030505 & 0.001285 \\
CBBT-N & 0.31 & 28.57 & 9.38 & 34.96 & 1.030510 & 0.001286 \\
CBBT-S & 0.31 & 28.70 & 9.36 & 34.98 & 1.030526 & 0.001286 \\
SBBT & 0.31 & 28.91 & 9.33 & 34.99 & 1.030542 & 0.001288 \\
JAM & 0.53 & 28.33 & 8.25 & 34.69 & 1.030496 & 0.001326 \\
MS2 & 1.15 & 26.48 & 11.53 & 35.52 & 1.030523 & 0.001215 \\
MS3 & 0.97 & 26.60 & 11.56 & 35.52 & 1.030518 & 0.001214 \\
MS4 & 0.74 & 27.11 & 11.35 & 35.45 & 1.030509 & 0.001221 \\
MS5 & 0.32 & 28.43 & 10.32 & 35.22 & 1.030529 & 0.001254 \\
\hline
\end{tabular}

Table 6. Values used to calculate sinking speeds (Eqs. 6-9). Densities of the bulk components were obtained from the literature.

\begin{tabular}{lll}
\hline & Value & Unit \\
\hline $\begin{array}{l}\text { POC-specific respiration } \\
\text { rate }(\lambda)\end{array}$ & 0.106 & day $^{-1}$ \\
Porosity & & \\
Radius & 0.917 & \\
\hline
\end{tabular}

Density of the ballast

material

\begin{tabular}{lll}
\hline OM & $0.90 \pm 0.20$ & $\mathrm{~g} \mathrm{~cm}^{-3}$ \\
Opal & $1.73 \pm 0.27$ & $\mathrm{~g} \mathrm{~cm}^{-3}$ \\
Carb. & $1.63 \pm 0.08$ & $\mathrm{~g} \mathrm{~cm}^{-3}$ \\
Lith. & $2.70 \pm 0.05$ & $\mathrm{~g} \mathrm{~cm}^{-3}$ \\
\hline
\end{tabular}

et al., 1996). Furthermore, it agrees with sinking speeds $\left(230 \pm 72 \mathrm{~m} \mathrm{day}^{-1}\right)$ obtained from the US JGOFS sediment trap experiment in the Arabian Sea (Berelson, 2001), lending credence to the values used to compute sinking velocities (Table 6). Due to the high mineral-specific density of lithogenic matter, it is a first-order driver of sinking speeds (Fig. 9a).

The calculated sinking speeds and satellite-derived export production permit us to calculate organic carbon fluxes (Eq. 10). Independent of which equation we used to compute export production, the calculated organic carbon fluxes correlate with the observations (Fig. 9b), but organic carbon fluxes obtained by using Eqs. (1) and (2) were higher and those obtained by using Eq. (3) were lower than the measured fluxes. The varying calculated organic carbon fluxes are a consequence of the different export production rates resulting from Eqs. (1) to (3) applied to satellite-derived primary production (see above). Equation 3 yielded the best agreement between measured and calculated fluxes and the highest correlation coefficient $(0.931)$. Nevertheless, the mean calculated organic carbon flux $\left(1.8 \mathrm{~g} \mathrm{~m}^{-2} \mathrm{yr}^{-1}\right)$ was lower than the mean measured organic carbon flux of $2.8 \mathrm{~g} \mathrm{~m}^{-2} \mathrm{yr}^{-1}$. Changing the constant in Eq. (3) from 0.23 to 0.37 increases the calculated flux and further improves the agreement between calculated and measured fluxes (Fig. 9c). This modification accounts for an underestimated primary and export production and/or a neglected protection of organic matter due to which we underestimate the strength of the ballast effect in our calculations.

To disentangle the roles of primary production and the ballast effect in organic carbon fluxes we recalculated organic carbon fluxes by using the modified Eq. (3). But instead of the speeds derived from the seawater properties and densities of the solids we used a constant sinking speed of $224 \mathrm{~m}$ day $^{-1}$. With this modification, organic carbon fluxes were calculated as a function of primary and export production only (Eq. 10). The resulting correlation coefficient was 0.926 for calculated and observed data obtained from stations at which the lithogenic matter content of sinking material was $<25 \%$ (Fig. 10). This correlation coefficient was almost as high as the one obtained from the correlation between 
Table 7. Carrying coefficients derived from the MLR applied to data measured at the trap sites (trap ID) including the mean. "No." indicates the number of data used for the analysis. The A trap shows the carrying coefficients derived by applying the MLR to the annual mean sediment data obtained from our sites (no.=11) and including the US JGOFS data (no.=17). The CA trap shows carrying coefficients obtained from all annual means (our data and US JGOFS data) including a constant term from Eq. (4).

\begin{tabular}{lrrr|rrr|rrr|rr}
\hline Trap ID & $\mathrm{CaCO}_{3}$ & SD & $P$ value & Opal & SD & $P$ value & Lith. & SD & $P$ value & $r^{2}$ & No. \\
\hline WAST & 0.044 & 0.007 & 0.000 & 0.046 & 0.007 & 0.000 & 0.132 & 0.018 & 0.000 & 0.958 & 142 \\
CAST & 0.018 & 0.007 & 0.008 & 0.198 & 0.032 & 0.000 & 0.120 & 0.026 & 0.000 & 0.955 & 88 \\
EAST & 0.033 & 0.007 & 0.000 & 0.124 & 0.020 & 0.000 & 0.108 & 0.014 & 0.000 & 0.970 & 115 \\
SAST & 0.011 & 0.004 & 0.034 & 0.049 & 0.028 & 0.111 & 0.256 & 0.029 & 0.000 & 0.998 & 13 \\
EIOT & 0.031 & 0.008 & 0.000 & 0.035 & 0.034 & 0.303 & 0.227 & 0.029 & 0.000 & 0.963 & 39 \\
NBBT-N & 0.090 & 0.011 & 0.000 & 0.070 & 0.015 & 0.000 & 0.046 & 0.005 & 0.000 & 0.973 & 88 \\
NBBT-S & -0.022 & 0.031 & 0.480 & 0.139 & 0.048 & 0.008 & 0.126 & 0.023 & 0.000 & 0.964 & 26 \\
CBBT-N & 0.096 & 0.008 & 0.000 & 0.057 & 0.012 & 0.000 & 0.033 & 0.005 & 0.000 & 0.972 & 78 \\
CBBT-S & 0.017 & 0.019 & 0.372 & 0.078 & 0.025 & 0.011 & 0.115 & 0.028 & 0.002 & 0.982 & 13 \\
SBBT & 0.041 & 0.006 & 0.000 & 0.073 & 0.011 & 0.000 & 0.115 & 0.014 & 0.000 & 0.960 & 99 \\
JAM & 0.128 & 0.026 & 0.000 & 0.034 & 0.013 & 0.010 & 0.022 & 0.005 & 0.000 & 0.943 & 54 \\
\hline Mean & 0.044 & 0.012 & & 0.082 & 0.022 & & 0.118 & 0.018 & & 1 \\
\hline A trap & 0.067 & 0.018 & 0.006 & 0.113 & 0.062 & 0.105 & 0.006 & 0.021 & 0.761 & 0.983 & 11 \\
A trap & 0.073 & 0.013 & 0.000 & 0.116 & 0.046 & 0.024 & 0.004 & 0.015 & 0.789 & 0.989 & 17 \\
CA trap & 0.066 & 0.018 & 0.002 & 0.120 & 0.048 & 0.026 & 0.002 & 0.016 & 0.913 & 0.922 & 17 \\
\hline
\end{tabular}

(a)

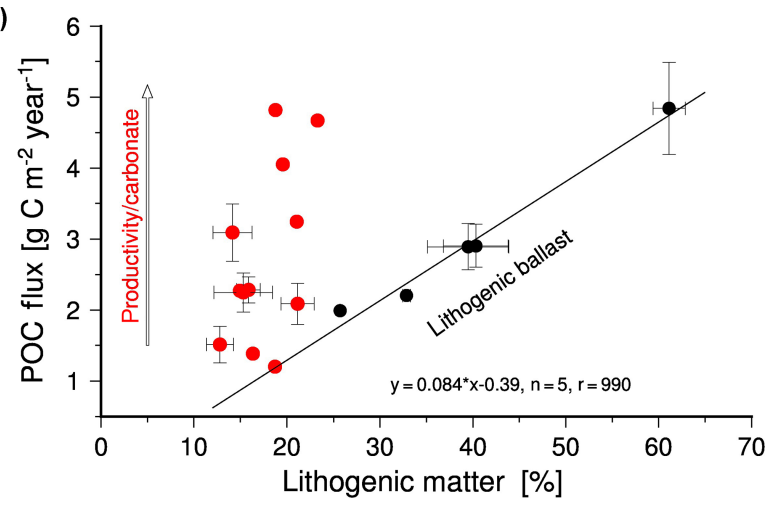

(b)

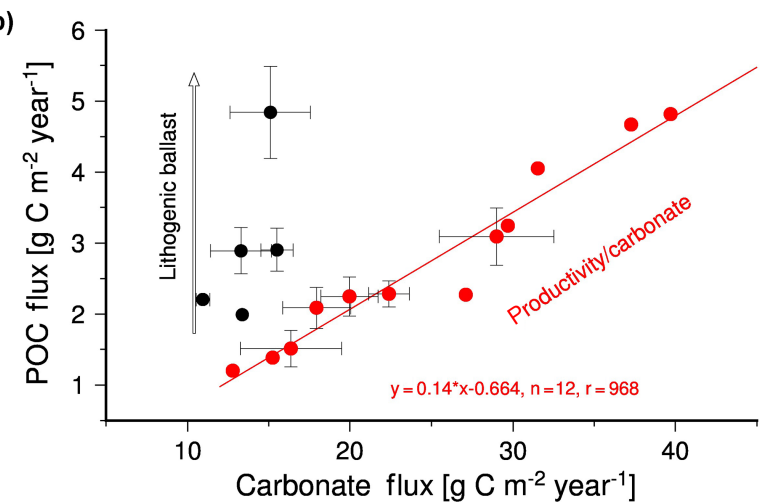

Figure 8. Organic carbon fluxes (POC) versus lithogenic matter content (a) and carbonate flux (b). The red and black circles indicate trap sites at which the annual mean lithogenic matter content is $<$ and $>25 \%$, respectively.
Table 8. Contribution of the individual ballast minerals to the predicted POC flux (RIB see Eq. 5).

\begin{tabular}{lrrr}
\hline Trap & $\mathrm{CaCO}_{3}$ & Opal & Lith. \\
\hline WAST & 47.0 & 17.8 & 35.1 \\
CAST & 21.1 & 46.2 & 32.7 \\
EAST & 31.0 & 30.9 & 38.1 \\
SAST & 13.4 & 12.8 & 73.8 \\
EIOT & 37.0 & 11.8 & 51.2 \\
NBBT-N & 42.8 & 24.5 & 32.7 \\
NBBT-S & -11.9 & 51.6 & 60.4 \\
CBBT-N & 55.2 & 21.4 & 23.4 \\
CBBT-S & 12.0 & 34.7 & 53.2 \\
SBBT & 36.0 & 30.9 & 33.1 \\
JAM & 41.1 & 19.1 & 39.7 \\
\hline Mean & 29.5 & 27.4 & 43.0 \\
\hline
\end{tabular}

measured fluxes and those derived from the site-specific sinking speeds $(0.931$; Fig. 9c). Accordingly, the adjustment of sinking speeds to differences in particulate matter composition and local seawater properties hardly improved the correlation between calculated and measured fluxes, and primary production is assumed to control the spatial variability of organic carbon fluxes at these sampling sites. At sites characterised by lithogenic matter content $>25 \%$ measured organic carbon fluxes and those derived from a constant sinking speed of $224 \mathrm{~m} \mathrm{day}^{-1}$ are also correlated (Fig. 10). Since calculated organic carbon fluxes were significantly lower than measured fluxes it is suggested that higher sinking speeds 

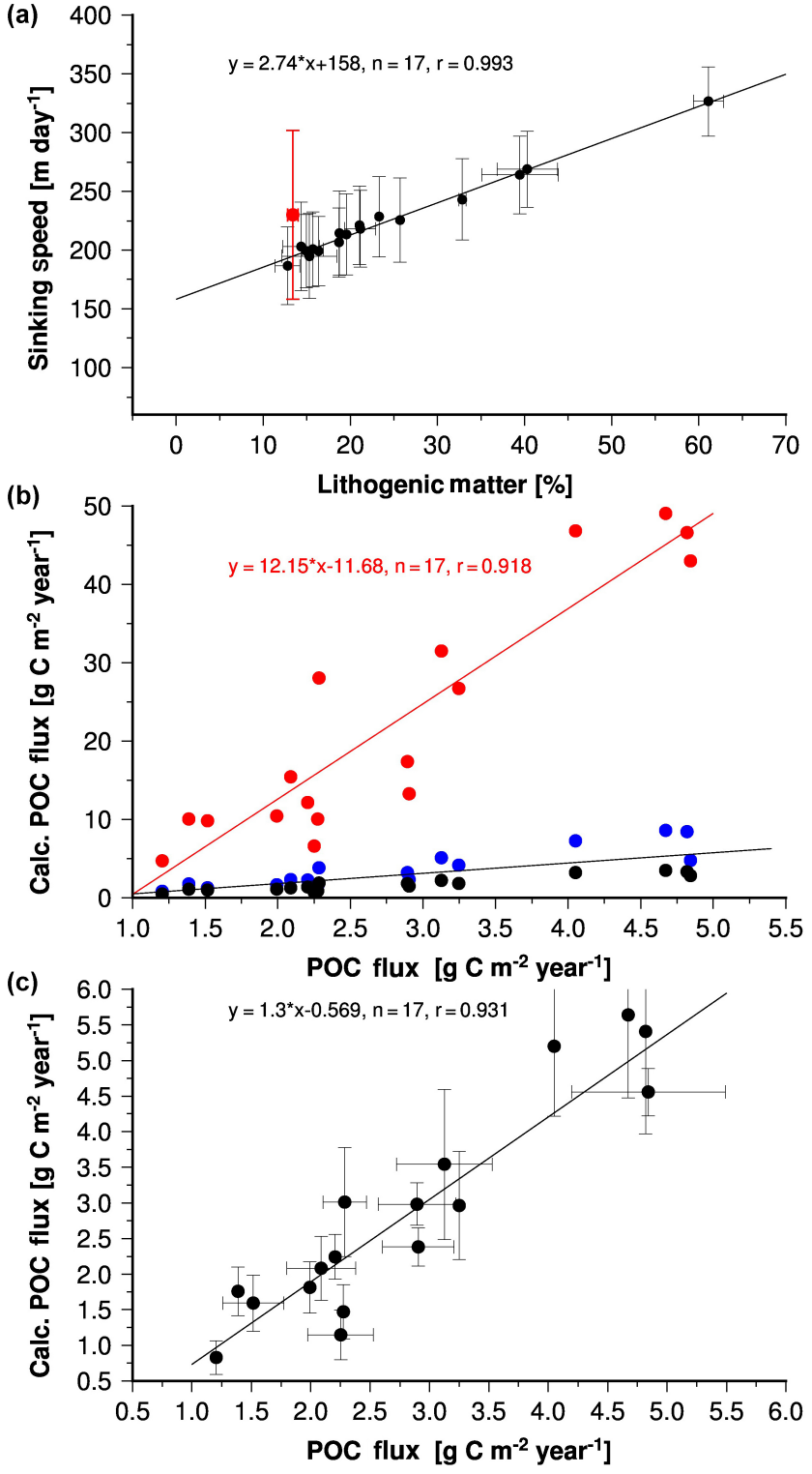

Figure 9. (a) Annual mean lithogenic matter content at the trap sites in the Indian Ocean versus sinking speeds derived from the seawater properties and the density of the solids (Eqs. 6-9) including the regression equation and line. The red circle indicates sinking speeds derived from the US JGOFS sediment trap sites in the western Arabian Sea (Berelson, 2001). (b) Annual mean organic carbon fluxes determined at the sediment trap sites versus organic carbon fluxes calculated by using Eq. (10) and sinking speeds shown in Fig. 9a. The export production was derived from Eqs. (1) (red circles), (2) (blue circles) and (3) (black circles). Red shows the regression equation and line obtained from the correlation between the calculated and measured fluxes, whereas the respective export production used to calculate the organic carbon flux was derived from Eq. (1). The black line indicates the $1: 1$ line. (c) Calculated versus measured fluxes as in Fig. 9b, but the modified Eq. (3) was used to calculate the required export production. The error bars indicate the interannual variability of the measured fluxes and the range caused the variability of the sinking speeds used to calculate the organic carbon flux.

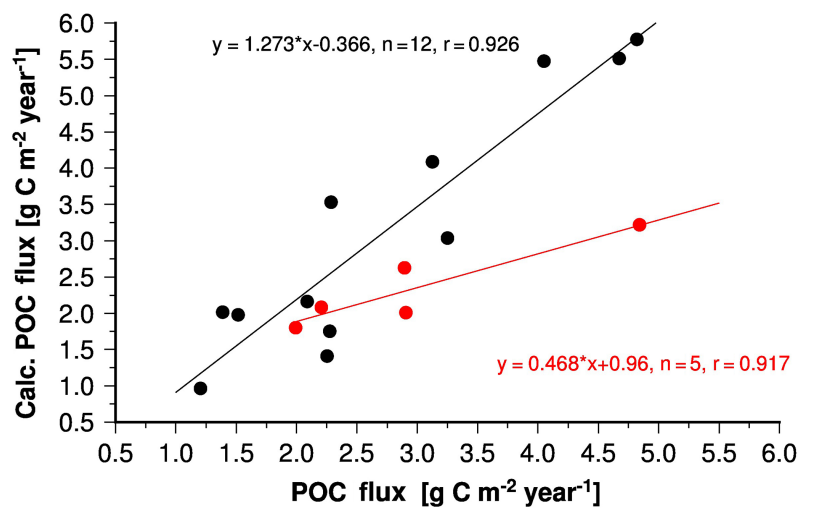

Figure 10. Calculated versus measured annual mean organic carbon fluxes. In addition to export production derived from primary production and the modified Eq. (3) a constant sinking speed of $224 \mathrm{~m} \mathrm{day}^{-1}$ was used to calculate organic carbon fluxes. Black and red circles indicate data obtained at sites characterised by low $(<25 \%)$ and high lithogenic matter content $(>25 \%)$, respectively.

induced by the lithogenic matter ballast effect determine organic carbon fluxes at these sites.

Equations (6)-(9) can be used to estimate the lithogenic matter effect on sinking speed. Therefore, the lithogenic matter flux was set to zero and the contribution of the other ballast minerals to the remaining total flux (total flux lithogenic matter flux) was recalculated. The difference between sinking speeds derived from the density of solids with and without considering lithogenic matter content $(\Delta$ sinking speed) reflects the impact of lithogenic matter on the sinking speeds and the strength of the lithogenic matter ballast effect (Fig. 11a). The strength of the lithogenic matter ballast effect increases with increasing lithogenic matter content (Fig. 11b). In the absence of lithogenic matter the mean sinking speed is $147 \pm 5 \mathrm{~m} \mathrm{day}^{-1}$, which implies that on average lithogenic matter enhances the sinking speed by $52 \%$ from 147 to $224 \mathrm{~m} \mathrm{day}^{-1}$ (Fig. 11a).

The impact of the lithogenic matter ballast effect on the organic carbon fluxes can be estimated by applying the reduced sinking speeds to Eq. (10) in addition to export production derived from primary production and the modified Eq. (3). In this case the mean calculated organic carbon fluxes are lower by $45 \%$ than those calculated by considering the lithogenic matter ballast effect on the sinking speeds. The difference between organic carbon fluxes calculated by using sinking speeds derived from the density of solids with and without considering lithogenic matter defines $\Delta$ POC flux, which in general increases with an increasing lithogenic matter ballast effect ( $\Delta$ sinking speeds; Fig. 11c). At site JAM the absence of lithogenic ballast reduces the organic carbon flux by $62 \%$, which implies, vice versa, that weighting with silicate strongly enhances organic carbon fluxes at JAM. This pronounced influence of lithogenic ballast is also the reason for higher measured organic carbon flux via a more rapid trans- 


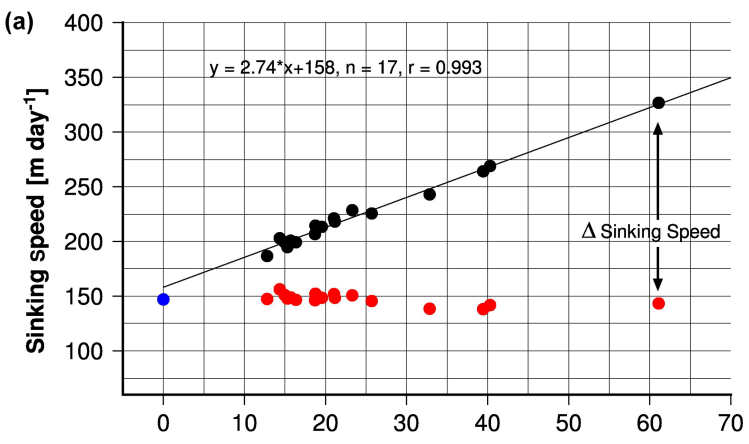

(b)
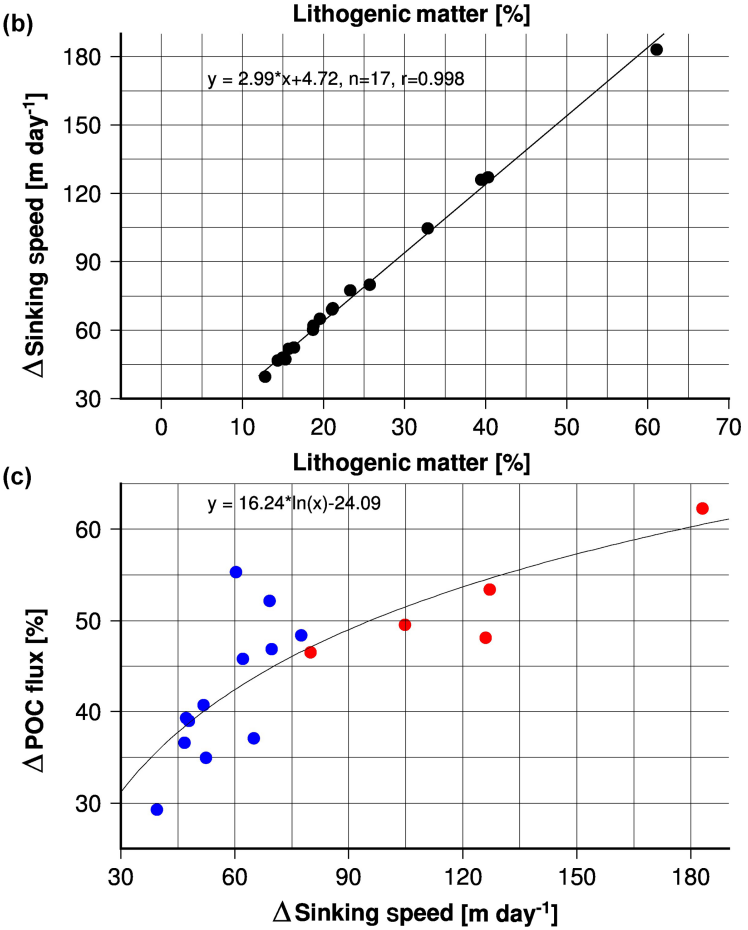

Figure 11. (a) Annual mean lithogenic matter content at the trap sites in the Indian Ocean versus sinking speeds derived from the density of the solids and seawater properties (black circles), including the regression equation and line as show in Fig. 9a, but without error bars. The red circles indicate sinking speeds derived from the density of the solids by setting the lithogenic matter flux to zero. These data were plotted versus the original lithogenic matter content to illustrate the differences between sinking speeds calculated with and without considering the lithogenic matter flux ( $\Delta$ sinking speed). The blue circle represents mean sinking speeds derived from the density of the solids by setting the lithogenic matter flux to zero (it represents the average of the data indicated by the red circles). (b) $\Delta$ sinking speed versus the annual mean lithogenic matter content at the trap sites in the Indian Ocean, including regression equation and line. (c) $\Delta$ POC flux versus $\Delta$ sinking speed. $\Delta$ POC flux is the difference between organic carbon fluxes derived from primary production and the modified Eq. (3) and sinking speeds derived from the density of solids with (POC1) and without considering lithogenic matter content (POC2). It is expressed as percentile deviation of the difference (POC1-POC2) from the organic carbon fluxes calculated based on the lithogenic matter contents (POC1). Positive values indicate that POC1 is larger than POC2. fer through the water column at JAM than at WAST, although the WAST site is far more productive.

This indicates that lithogenic matter ballast is an important factor enhancing organic carbon fluxes at all sites in the Indian Ocean. Such a strong lithogenic matter ballast effect emphasises the role of land use changes in the residence time of regenerated $\mathrm{CO}_{2}$ and the associated $\mathrm{CO}_{2}$ uptake efficiency of the organic carbon pump. Considering that the Neolithic revolution was accompanied by a 20 -fold increase in erosion in the wake of deforestation and the expansion of agriculture (Neil, 2014), humans must have increased the ballast effect and the $\mathrm{CO}_{2}$ uptake of the organic carbon pump, particularly in regions under river influence, for thousands of years.

\section{Conclusions}

The evaluation of data from sediment trap time series in conjunction with satellite-derived observations suggests that at sites characterised by low lithogenic matter contents $(<25 \%)$ primary production is the dominant control of the spatial variability of organic carbon fluxes into the deep ocean. A pronounced lithogenic matter ballast effect overrides primary production as the main influence on sinking organic carbon fluxes in ocean areas under river influence. However, the lithogenic matter ballast effect strongly enhances the amount of organic carbon reaching the deep ocean at all sampling sites in the Indian Ocean. Calculated sinking speeds and organic carbon fluxes indicate that the lithogenic matter ballast effect increased the mean sinking speeds by $52 \%$ and the mean calculated organic carbon flux by $45 \%$. Due to the high lithogenic matter content the lithogenic matter ballast effect even enhanced organic carbon fluxes by $>62 \%$ off southern Java so that organic carbon fluxes are higher in the low-productive southern Java Sea compared to the highproductive western Arabian Sea upwelling area. This implies that land use changes affect the $\mathrm{CO}_{2}$ uptake of the organic carbon pump by increasing lithogenic matter inputs into the ocean.

Data availability. The data set is available on the repository of PANGEA at https://doi.org/10.1594/PANGAEA.879702 (Rixen et al., 2017).

Author contributions. TR, BG and VR participated in the field data collection and in the analysis of samples. All authors discussed results and wrote the paper.

Competing interests. The authors declare that they have no conflict of interest. 
Special issue statement. This article is part of the special issue "Progress in quantifying ocean biogeochemistry - in honour of Ernst Maier-Reimer". It is not associated with a conference.

Acknowledgements. First of all, we would like to thank the large group of scientists, technicians, officers and crews of the numerous research expeditions in the Indian Ocean that laid the foundation for this work. We specifically express our gratitude to the Federal German Ministry for Education, Science, Research and Technology (BMBF, Bonn; ref. no. 03F0463A), the Council of Scientific and Industrial Research (CSIR, New Delhi), the Ministry of Earth Sciences (MOES, New Delhi), and the Agency for the Assessment and Application of Technology (BPPT), Jakarta, Indonesia, for financial support. Paul Wessels and Walter H. F. Smith are acknowledged for providing the generic mapping tools (GMTs). Several reviewers are acknowledged for helpful comments and criticism that significantly improved this contribution.

The publication of this article was funded by the

Open Access Fund of the Leibniz Association.

Edited by: Christoph Heinze

Reviewed by: Jamie Wilson and one anonymous referee

\section{References}

Alldredge, A. L. and Gotschalk, C.: In situ setting behavior of marine snow, Limnol. Oceanogr., 33, 339-351, 1988.

Antia, A. N.: Solubilization of particles in sediment traps: revising the stoichiometry of mixed layer export, Biogeosciences, 2, 189204, https://doi.org/10.5194/bg-2-189-2005, 2005.

Armstrong, R. A., Lee, C., Hedges, J. I., Honjo, S., and Wakeham, S.: A new, mechanistic model for organic carbon fluxes in the ocean: based on the quantitative association of POC with ballast minerals, Deep-Sea Res., 49, 219-236, 2002.

Azetsu-Scott, K. and Passow, U.: Ascending marine particles: Significance of transparent exopolymer particles (TEP) in the upper ocean, Limnol. Oceanogr., 49, 741-748, 2004.

Banse, K.: New views on the degradation and disposition of organic particles as collected by sediment traps in the open sea, Deep-Sea Res., 37, 1177-1195, 1990.

Bauer, S., Hitchcock, G. L., and Olson, D. B.: Influence of monsoonally-forced Ekman dynamics upon surface layer depth and plankton biomass distribution in the Arabian Sea, Deep-Sea Res., 38, 531-553, 1991.

Behrenfeld, M. J. and Falkowski, P. G.: Photosynthetic rates derived from satellite-based chlorophyll concentration, Limnol. Oceanogr., 42, 1-20, 1997.

Berelson, W. M.: Particle settling rates increase with depth in the ocean, Deep-Sea Res. Pt. II, 49, 237-251, 2001.

Bianchi, D., Galbraith, E. D., Carozza, D. A., Mislan, K. A. S., and Stock, C. A.: Intensification of open-ocean oxygen depletion by vertically migrating animals, Nat. Geosci., 6, 545-548, 2013.

Broecker, W. S., Takahashi, T., and Takahashi, T.: Sources and Flow Patterns of Deep-Ocean Waters as Deduced From Potential Temperature, Salinity, and Initial Phosphate Concentration, J. Geophys. Res., 90, 6925-6939, 1985.
Buesseler, K. O., Bacon, M. P., Kirk Cochran, J., and Livingston, H. D.: Carbon and nitrogen export during the JGOFS North Atlantic Bloom experiment estimated from ${ }^{234} \mathrm{Th}:{ }^{238} \mathrm{U}$ disequilibria, Deep-Sea Res. Pt. A, 39, 1115-1137, 1992.

Buesseler, K. O., Antia, A. N., Chen, M., Fowler, S. W., Gardner, W. D., Gustafsson, O., Harada, K., Michaels, A. F., Rutgers van der Loeff, M., Sarin, M., Steinberg, D. K., and Trull, T.: An assessment of the use of sediment traps for estimating upper ocean particle fluxes, J. Mar. Res., 65, 345-416, 2007.

Clemens, S., Prell, W., Murray, D., Shimmield, G., and Weedon, G.: Forcing mechanisms of the Indian Ocean monsoon, Nature, 353, 720-725, 1991.

Csögör, Z., Melgar, D., Schmidt, K., and Posten, C.: Production and particle characterization of the frustules of Cyclotella cryptica in comparison with siliceous earth, J. Biotechnol., 70, 71-75, 1999.

Currie, R. I., Fisher, A. E., and Hargreaves, P. M.: Arabian Sea Upwelling, in: Biology of the Indian Ocean, edited by: Zeitschel, B., Berlin, Springer Verlag, 549, 37-52, 1973.

De La Rocha, C. L. and Passow, U.: 8.4 - The Biological Pump, in: Treatise on Geochemistry (2nd edn.), edited by: Turekian, H. D. H. K., Elsevier, Oxford, 2014.

del Giorgio, P. A. and Duarte, C. M.: Respiration in the open ocean, Nature, 420, 379-384, 2002.

DeMaster, D. J.: 7.04 - The Diagenesis of Biogenic Silica: Chemical Transformations Occurring in the Water Column, Seabed, and Crust A2 - Turekian, in: Treatise on Geochemistry, edited by: Heinrich, D. and HollandKarl, K., Pergamon, Oxford, 2003.

DeVries, T., Primeau, F., and Deutsch, C.: The sequestration efficiency of the biological pump, Geophys. Res. Lett., 39, L13601, https://doi.org/10.1029/2012gl051963, 2012.

Dugdale, R. C. and Goering, J. J.: Uptake of new and regenerated forms of nitrogen in primary productivity, Limnol. Oceanogr., 12, 196-206, 1967.

Durkin, C. A., Estapa, M. L., and Buesseler, K. O.: Observations of carbon export by small sinking particles in the upper mesopelagic, Mar. Chem., 175, 72-81, 2015.

Duteil, O., Koeve, W., Oschlies, A., Aumont, O., Bianchi, D., Bopp, L., Galbraith, E., Matear, R., Moore, J. K., Sarmiento, J. L., and Segschneider, J.: Preformed and regenerated phosphate in ocean general circulation models: can right total concentrations be wrong?, Biogeosciences, 9, 1797-1807, https://doi.org/10.5194/bg-9-1797-2012, 2012.

Engel, A., Szlosek, J., Abramson, L., Liu, Z., and Lee, C.: Investigating the effect of ballasting by $\mathrm{CaCO}_{3}$ in Emiliania huxleyi: I. Formation, settling velocities and physical properties of aggregates, Deep-Sea Res. Pt. II, 56, 1396-1407, 2009.

Eppley, R. W. and Peterson, B. J.: Particulate organic matter flux and planktonic new production in the deep ocean, Nature, 282, 677-680, 1979.

Findlater, J.: A major low-level air current near the Indian Ocean during the northern summer, Q. J. R. Meteor. Soc., 95, 362-380, 1969.

Findlater, J.: A Numerical Index to Monitor the Afro-Asian Monsoon During the Northern Summers, Meteorol. Mag., 106, 170 180, 1977.

Francois, R., Honjo, S., Krishfield, R., and Manganini, S.: Factors controlling the flux of organic carbon to the bathypelagic zone of the ocean, Global Biogeochem. Cy., 16, 1087, https://doi.org/10.1029/2006jc003706, 2002. 
Guidi, L., Stemmann, L., Jackson, G. A., Ibanez, F., Claustre, H., Legendre, L., Picheral, M., and Gorskya, G.: Effects of phytoplankton community on production, size, and export of large aggregates: A world-ocean analysis, Limnol. Oceanogr., 54, 19511963, 2009.

Haake, B. and Ittekkot, V.: Die Wind-getriebene "biologische Pumpe" und der Kohlenstoffentzug im Ozean, Naturwissenschaften, 77, 75-79, 1990.

Haake, B., Ittekkot, V., Rixen, T., Ramaswamy, V., Nair, R. R., and Curry, W. B.: Seasonality and interannual variability of particle fluxes to the deep Arabian Sea, Deep-Sea Res. Pt. I, 40, 13231344, 1993.

Hamm, C. E.: Interactive aggregation and sedimentation of diatoms and clay-sized lithogenic material, Limnol. Oceanogr., 47, 17901795, 2002.

Heinze, C., Maier-Reimer, E., and Winn, K.: Glacial $p \mathrm{CO}_{2}$ Reduction by the World Ocean: Experiments with the Hamburg Carbon Cycle Model, Paleoceanography, 6, 395-430, 1991.

Hendiarti, N., Siegel, H., and Ohde, T.: Investigation of different coastal processes in Indonesian water using SeaWiFS data, Deep-Sea Res., 51, 85-97, 2004.

Henson, S. A., Sanders, R., Madsen, E., Morris, P. J., Le Moigne, F., and Quartly, G. D.: A reduced estimate of the strength of the ocean's biological carbon pump, Geophys. Res. Lett., 38, L04606, https://doi.org/10.1029/2011gl046735, 2011.

Honjo, S.: Coccoliths: Production, Transportation and Sedimentation, Mar. Micropaleontol., 1, 65-79, 1976.

Honjo, S., Dymond, J., Prell, W., and Ittekkot, V.: Monsooncontrolled export fluxes to the interior of the Arabian Sea, DeepSea Res. Pt. II, 46, 1859-1902, 1999.

Honjo, S., Manganini, S. J., Krishfield, R. A., and Francois, R.: Particulate organic carbon fluxes to the ocean interior and factors controlling the biological pump: A synthesis of global sediment trap programs since 1983, Prog. Oceanogr., 76, 217-285, 2008.

IOC, SCOR, and IAPSO: The international thermodynamic equation of seawater - 2010: Calculation and use of thermodynamic properties., Intergovernmental Oceanographic Commission UNESCO Manuals and Guides, 196 pp., 2010.

Ito, T. and Follows, M. J.: Preformed phosphate, soft tissue pump and atmospheric $\mathrm{CO}_{2}$, J. Mar. Res., 63, 813-839, 2005.

Ittekkot, V.: The abiotically driven biological pump in the ocean and short-term fluctuations in atmospheric $\mathrm{CO}_{2}$ contents, Global and Planet. Change, 8, 17-25, 1993.

Ittekkot, V. and Haake, B.: The Terrestrial Link in the Removal of Organic Carbon in the Sea, in: Factes of Modern Biogeochemistry, edited by: Ittekkot, V., Kempe, S., Michaelis, W., and Spitzy, A., Springer Verlag, Berlin, Heidelberg, New York, 1990.

Ittekkot, V., Nair, R. R., Honjo, S., Ramaswamy, V., Bartsch, M., Manganini, S., and Desai, B. N.: Enhanced particle fluxes in Bay of Bengal induced by injection of fresh water, Nature, 351, 385387, 1991

Iversen, M. H., Nowald, N., Ploug, H., Jackson, G. A., and Fischer, G.: High resolution profiles of vertical particulate organic matter export off Cape Blanc, Mauritania: Degradation processes and ballasting effects, Deep-Sea Res. Pt. I, 57, 771-784, 2010.

Iversen, M. H. and Ploug, H.: Ballast minerals and the sinking carbon flux in the ocean: carbon-specific respiration rates and sinking velocity of marine snow aggregates, Biogeosciences, 7 , 2613-2624, https://doi.org/10.5194/bg-7-2613-2010, 2010.
Iversen, M. H. and Ploug, H.: Temperature effects on carbonspecific respiration rate and sinking velocity of diatom aggregates - potential implications for deep ocean export processes, Biogeosciences, 10, 4073-4085, https://doi.org/10.5194/bg-104073-2013, 2013.

Klaas, C. and Archer, D. E.: Association of sinking organic matter with various types of mineral ballast in the deep sea: Implications for the rain ratio, Global Biogeochem. Cy., 16, 1116, https://doi.org/10.1029/2001GB001765, 2002.

Knox, F. and McElroy, M. B.: Changes in atmospheric $\mathrm{CO}_{2}$ : Influence of the marine biota at high latitude, J. Geophys. Res.Atmos., 89, 4629-4637, 1984.

Kumar, D., M., Naqvi, S. W. A., George, M. D., and Jayakumar, A.: A sink for atmospheric carbon dioxide in the northeastern Indian Ocean, J. Geophys. Res., 101, 18121-118125, 1996.

Kwon, E. Y., Primeau, F., and Sarmiento, J. L.: The impact of remineralization depth on the air-sea carbon balance, Nat. Geosci. 2, 630-635, 2009

Lal, D. and Lerman, A.: Size spectra of biogenic particles in ocean water and sediments, J. Geophys. Res., 80, 423-430, 1975.

Laufkötter, C., John, J. G., Stock, C. A., and Dunne, J. P.: Temperature and oxygen dependence of the remineralization of organic matter, Global Biogeochem. Cy., 31, 1038-1050, 2017.

Laws, E. A., Falkowski, P. G., Smith, W. O., Ducklow, H., and McCarthy, J. J.: Temperature effects on export production in the open ocean, Global Biogeochem. Cy., 14, 1231-1246, 2000.

Lee, C., Murray, D. W., Barber, R. T., Buesseler, K. O., Dymond, J., Hedges, J. I., Honjo, S., Manganini, S. J., and Marra, J.: Particulate organic carbon fluxes: compilation of results from the 1995 US JGOFS Arabian Sea Process Study, Deep-Sea Res. Pt. II, 45, 2489-2501, 1998.

Lee, C., Wakeham, S. G., and Arnosti, C.: Particulate organic matter in the sea: the composition conundrum, Ambio, 33, 565-575, 2004.

Locarnini, R. A., Mishonov, A. V., Antonov, J. I., Boyer, T. P., Garcia, H. E., Baranova, O. K., Zweng, M. M., Paver, C. R., Reagan, J. R., Johnson, D. R., Hamilton, M., and Seidov, D.: World Ocean Atlas 2013, National Oceanographic Data Center(NODC), 2013.

Logan, B. E. and Hunt, J. R.: Advantages to microbes of growth in permeable aggregates in marine systems 1 , Limnol. Oceanogr., 32, 1034-1048, 1987.

Ludwig, W., Probst, J.-L., and Kempe, S.: Predicting the oceanic input of organic carbon by continental erosion, Global Biogeochem. Cy., 10, 23-41, 1996.

Luther, M. E. and O'Brien, J. J.: Variability in Upwelling Fields in the Northwestern Indian Ocean - 1. Model Experiments for the Past 18,000 Years, Paleoceanography, 5, 433-445, 1990.

Lutz, M. J., Caldeira, K., Dunbar, R. B., and Behrenfeld, M. J.: Seasonal rhythms of net primary production and particulate organic carbon flux to depth describe the efficiency of biological pump in the global ocean, J. Geophys. Res.-Ocean., 112, C10011, https://doi.org/10.1029/2008PA001636, 2007.

Marsay, C. M., Sanders, R. J., Henson, S. A., Pabortsava, K., Achterberg, E. P., and Lampitt, R. S.: Attenuation of sinking particulate organic carbon flux through the mesopelagic ocean, P. Natl. Acad. Sci. USA, 112, 1089-1094, 2015.

McCave, I. N.: Vertical flux of particles in the ocean, Deep-Sea Res., 22, 491-502, 1975 
McDonnell, A. M. P., Boyd, P. W., and Buesseler, K. O.: Effects of sinking velocities and microbial respiration rates on the attenuation of particulate carbon fluxes through the mesopelagic zone, Global Biogeochem. Cy., 29, 175-193, 2015.

Miklasz, K. A. and Denny, M. W.: Diatom sinkings speeds: Improved predictions and insight from a modified Stokes' law, Limnol. Oceanogr., 55, 2513-2525, 2010.

Milliman, J. D. and Farnsworth, K. L.: River discharge to the coastal ocean, Cambridge University Press, Cambridge, 2011.

Milliman, J. D. and Meade, R. H.: World-Wide Delivery of River Sediment to the Oceans, J. Geol., 91, 1-21, 1983.

Milliman, J. D., Quraishee, G. S., and Beg, M. A. A.: Sediment discharge from the Indus River to the ocean: past, present and future, in: Marine Geology and Oceanography of Arabian Sea and Coastal Pakistan, edited by: Haq, B. U. and Milliman, J. D., Van Nostrand Reinhold Company Scientific and Academic Editions, New York, Cincinnati, Stroudsburg, Toronto, London, Melbourne, 1984.

Mohtadi, M., Steinke, S., Groeneveld, J., Fink, H., G., Rixen, T., Hebbeln, D., Donner, B., and Herunadi, B.: Lowlatitude control on seasonal and interannual changes in planktonic foraminiferal flux and shell geochemistry off south Java: A sediment trap study, Paleoceanography, 24, PA1201, https://doi.org/10.1029/2006GB002688, 2009.

Mottana, A., Crespi, R., and Liborio, G.: Simon \& Schuster's guide to rocks \& minerals, Simon and Schuster, New York, 1978.

Nair, R. R., Ittekkot, V., Manganini, S. J., Ramaswamy, V., Haake, B., Degens, E. T., Desai, B. N., and Honjo, S.: Increased particle flux to the deep ocean related to monsoons, Nature, 338, 749$751,1989$.

Neil, R.: The Holocene: An Environmental History, WileyBlackwell, Hoboken, New Jersey USA, 2014.

Osipov, V. I.: Density of clay minerals, Soil Mech. Found. Eng., 48, 231-240, 2012.

Ploug, H. and Grossart, H.-P.: Bacterial growth and grazing on diatom aggregates: Respiratory carbon turnover as a function of aggregate size and sinking velocity, Limnol. Oceanogr., 45, 1467$1475,2000$.

Quillin, M. L. and Matthews, B. W.: Accurate calculation of the density of proteins, Acta Crystallogr. D, 56, 791-794, 2000.

Ragueneau, O., Schultes, S., Bidle, K., Claquin, P., and Moriceau, $\mathrm{B}$.: $\mathrm{Si}$ and $\mathrm{C}$ interactions in the world ocean: Importance of ecological processes and implications for the role of diatoms in the biological pump, Global Biogeochem. Cy., 20, GB4S02, https://doi.org/10.1029/2006GB002688, 2006.

Ramage, C. S.: Monsoon Climates, in: The Encyclopedia of Climatology, edited by: Oliver, J. E. and Fairbridge, R. W., Van Nostrand Reinhold Company, New York, 1987.

Ramage, C. S.: Monsoon Meteorology, Academic Press, New York, London, 1971.

Ramaswamy, V., Nair, R. R., Manganini, S., Haake, B., and Ittekkot, V.: Lithogenic fluxes to the deep Arabian Sea measured by sediment traps, Deep-Sea Res., 38, 169-184, 1991.

Ramaswamy, V., Vijay Kumar, B., Parthiban, G., Ittekkot, V., and Nair, R. R.: Lithogenic fluxes in the Bay of Bengal measured by sediment traps, Deep-Sea Res. Pt. I, 44, 793-810, 1997.

Rao, C. K., Naqvi, S. W. A., Kumar, M. D., Varaprasad, S. J. D., Jayakumar, D. A., George, M. D., and Singbal, S. Y. S.: Hydrochemistry of the Bay of Bengal: possible reasons for a different water-column cycling of carbon and nitrogen from the Arabian Sea, Mar. Chem., 47, 279-290, 1994.

Rex, R. W. and Goldberg, E. D.: Quartz Contents of Pelagic Sediments of the Pacific Ocean1, Tellus, 10, 153-159, 1958.

Risien, C. M. and Chelton, D. B.: A Global Climatology of Surface Wind and Wind Stress Fields from Eight Years of QuikSCAT Scatterometer Data, J. Phys. Oceanogr., 38, 2379-2413, 2008.

Rixen, T., Haake, B., Ittekkot, V., Guptha, M. V. S., Nair, R. R., and Schlüssel, P.: Coupling between SW monsoon-related surface and deep ocean processes as discerned from continuous particle flux meausurements and correlated satellite data, J. Geophys. Res., 101, 28569-528582, 1996.

Rixen, T., Guptha, M. V. S., and Ittekkot, V.: Sedimentation, in: Report of the Indian Ocean Synthesis Group on the Arabian Sea Process Study, edited by: Watts, L., Burkill, P. H., and Smith, S., JGOFS International Project Office, Bergen, 2002.

Rixen, T., Ittekkot, V., Herundi, B., Wetzel, P., Maier-Reimer, E., and Gaye-Haake, B.: ENSO-driven carbon see saw in the Indo-Pacific, J. Geophys. Res. Lett., 33, L07606, https://doi.org/10.1029/2005GL024965, 2006.

Rixen, T., Ramaswamy, V., Gaye, B., Herunadi, B., Maier-Reimer, E., Bange, H. W., and Ittekkot, V.: Monsoonal and ENSO Impacts on Export Fluxes and the Biological Pump in the Indian Ocean, in: Indian Ocean Biogeochemical Processes and Ecological Variability, edited by: Hood, R. R., Wiggert, J. D., Naqvi, S W. A., Smith , S., and Brink , K., 185, AGU, Washington, 2009.

Rixen, T., Gaye, B., Emeis, K.-C., Ramaswamy, V., and Ittekkot, V.: Particle fluxes obtained from sediment trap experiments in the northern Indian Ocean, PANGAEA, https://doi.org/10.1594/PANGAEA.879702, 2017.

Rochford, D. J.: Source regions of oxygen maxima in intermediate depths of the Arabian Sea, Mar. Freshw. Res., 17, 1-30, 1966.

Romero, O. E., Rixen, T., and Herunadi, B.: Effects of hydrographic and climatic forcing on diatom production and export in the tropical southeastern Indian Ocean, Mar. Ecol. Prog. Ser., 384, 6982, https://doi.org/10.3354/meps08013, 2009.

Ryther, J. H. and Menzel, D. W.: On the production composition and distribution of organic matter in the Western Arabian Sea, Deep-Sea Res., 12, 199-209, 1965.

Sarmiento, J. L. and Toggweiler, J. R.: A new model for the role of the oceans in determining atmospheric $p \mathrm{CO}_{2}$, Nature, 308, 621-624, 1984.

Sastry, J. S. and D'Souza, R. S.: Upwelling \& Upward Mixing in the Arabian Sea, Indian J. Mar. Sci., 1, 17-27, 1972.

Schiebel, R.: Planktic foraminiferal sedimentation and the marine calcite budget, Global Biogeochem. Cy., 16, 1065, https://doi.org/10.1029/2001GB001459, 2002.

Schiebel, R. and Hemleben, C.: Interannual variability of planktic foraminiferal populations and test flux in the eastern North Atlantic Ocean (JGOFS), Deep-Sea Res. Pt. II, 47, 1809-1852, 2000.

Schiebel, R. and Hemleben, C.: Modern planktic foraminifera, Palaeont. Z., 79, 135-148, 2005.

Schiebel, R., Barker, S., Lendt, R., Thomas, H., and Bollmann, J.: Planktic foraminiferal dissolution in the twilight zone, Deep-Sea Res. Pt. II, 54, 676-686, 2007.

Schmidt, K., De La Rocha, C. L., Gallinari, M., and Cortese, G.: Not all calcite ballast is created equal: differing effects of foraminiferan and coccolith calcite on the forma- 
tion and sinking of aggregates, Biogeosciences, 11, 135-145, https://doi.org/10.5194/bg-11-135-2014, 2014.

Sharma, G. S.: Upwelling Off the Soutwest Coast of India, Indian J. Mar. Sci., 7, 209-218, 1978.

Shetye, S. R., Gouveia, A. D., Shenoi, S. S. C., Sundar, D., Michael, G. S., Almeida, A. M., and Santanam, K.: Hydrography and circulation off the west coast of India during the Southwest Monsoon 1987, J. Mar. Res., 48, 359-378, 1990.

Siegenthaler, U. and Wenk, T.: Rapid atmospheric $\mathrm{CO}_{2}$ variations and ocean circulation, Nature, 308, 624-627, 1984.

Sirocko, F., Sarnthein, M., Erlenkeuser, H., Lange, H., Arnold, M., and Duplessy, J. C.: Century-scale events in monsoonal climate over the past 24,000 years, Nature, 364, 322-324, 1993.

Smith, T. M., Reynolds, R. W., Peterson, T. C., and Lawrimore, J.: Improvements to NOAA's historival merged land-ocean surface temperature analysis (1880-2006), J. Clim., 21, 2283-2296, 2008.

Subramanian, V., Richey, J. E., and Abbas, N.: Geochemistry of River Basins of India Part II - Preliminary Studies on the Particulate $\mathrm{C}$ and $\mathrm{N}$ in the Ganges-Brahmaputra River System, Mitt. Geol.-Paläont. Inst. Univ. Hamburg, 58, 513-518, 1985.

Susanto, R. D., Gordon, A. L., and Zengh, Q.: Upwelling along the coasts of Java and Sumatra and its relation to ENSO, J. Mar. Res. Lett., 28, 1599-1602, 2001.

Syvitski, J. P. M., Vörösmarty, C. J., A.J., K., and Green, P.: Impact of humans on the flux of terrestrial sediment to the global ocean, Science, 308, 376-380, 2005.

Tchernia, P.: Descriptive regional oceanography, Oxford Pergamon Press, Oxford, UK, 1980.

Tegen, I. and Fung, I.: Contribution to the atmospheric mineral aerosol load from land surface modification, J. Geophys. Res., 100, 18707-718726, 1995.

Turner, J. T.: Zooplankton fecal pellets, marine snow, phytodetritus and the ocean's biological pump, Prog. Oceanogr., 130, 205-248, 2015.
Unger, D., Ittekkot, V., Schafer, P., Tiemann, J., and Reschke, S.: Seasonality and interannual variability of particle fluxes to the deep Bay of Bengal: influence of riverine input and oceanographic processes, Deep-Sea Res. Pt. II, 50, 897-923, 2003.

Usbeck, R., Schlitzer, R., Fischer, G., and Wefer, G.: Particle fluxes in the ocean: comparison of sediment trap data with results from inverse modeling, J. Mar. Syst., 39, 167-183, 2003.

Volk, T. and Hoffert, M. I.: The carbon cycle and atmospheric $\mathrm{CO}_{2}$, natural variation archean to present, in: The Carbon Cycle and Atmospheric $\mathrm{CO}_{2}$ : Natural Variations Archean to Present, edited by: Sundquist, E. T. and Broecker, W. S., AGU, Washington, 1985.

Wagner, W. and Pruß, A.: The IAPWS Formulation 1995 for the Thermodynamic Properties of Ordinary Water Substance for General and Scientific Use, J. Phys. Chem. Ref. Data, 31, 387535, 2002.

Wiggert, J. D., Murtugudde, R. G., and Christian, J. R.: Annual ecosystem variability in the tropical Indian Ocean: Results of a coupled bio-physical ocean general circulation model, Deep-Sea Res. Pt. II, 53, 644-676, 2006.

Wilson, J. D., Barker, S., and Ridgwell, A.: Assessment of the spatial variability in particulate organic matter and mineral sinking fluxes in the ocean interior: Implications for the ballast hypothesis, Global Biogeochem. Cy., 26, GB4011, https://doi.org/10.1029/2012gb004398, 2012.

Winter, A. and Siesser, W. G.: Coccolithophores, Cambridge University Press, New York, 1994.

Yu, E.-F., Francois, R., Bacon, M. P., Honjo, S., Fleer, A. P., Manganini, S. J., Rutgers van der Loeff, M. M., and Ittekkot, V.: Trapping efficiency of bottom-tethered sediment traps estimated from the intercepted fluxes of ${ }^{230} \mathrm{Th}$ and ${ }^{231} \mathrm{~Pa}$, Deep-Sea Res. Pt. I, 48, 865-889, 2001.

Zweng, M. M., Reagan, J. R., Antonov, J. I., Locarnini, R. A., Mishonov, A. V., Boyer, T. P., Garcia, H. E., Baranova, O. K., Paver, C. R., Johnson, D. R., Seidov, D., and Biddle, M.: World Ocean Atlas 2013, National Oceanographic Data Center(NODC), 2013. 